\title{
Metabolic Hormones Modulate Macrophage Inflammatory Responses
}

\author{
Matthew J. Batty, Gwladys Chabrier, Alanah Sheridan (D) and Matthew C. Gage *D \\ Department of Comparative Biomedical Sciences, Royal Veterinary College, 4 Royal College Street, \\ London NW1 0TU, UK; mb2439@cam.ac.uk (M.J.B.); gchabrier@rvc.ac.uk (G.C.); asheridan20@rvc.ac.uk (A.S.) \\ * Correspondence: mgage@rvc.ac.uk
}

Simple Summary: Macrophages are a type of immune cell which play an important role in the development of cancer. Obesity increases the risk of cancer and obesity also causes disruption to the normal levels of hormones that are produced to coordinate metabolism. Recent research now shows that these metabolic hormones also play important roles in macrophage immune responses and so through macrophages, disrupted metabolic hormone levels may promote cancer. This review article aims to highlight and summarise these recent findings so that the scientific community may better understand how important this new area of research is, and how these findings can be capitalised on for future scientific studies.

Abstract: Macrophages are phagocytotic leukocytes that play an important role in the innate immune response and have established roles in metabolic diseases and cancer progression. Increased adiposity in obese individuals leads to dysregulation of many hormones including those whose functions are to coordinate metabolism. Recent evidence suggests additional roles of these metabolic hormones in modulating macrophage inflammatory responses. In this review, we highlight key metabolic hormones and summarise their influence on the inflammatory response of macrophages and consider how, in turn, these hormones may influence the development of different cancer types through the modulation of macrophage functions.

Keywords: macrophages; hormones; TAMs; obesity; polarisation; metabolism; inflammation; cancer

Academic Editors: Lisardo Bosca,

Antonio Castrillo, Eduardo

Lopez-Collazo and Mary Frances

McMullin

Received: 1 July 2021

Accepted: 13 September 2021

Published: 17 September 2021

Publisher's Note: MDPI stays neutral with regard to jurisdictional claims in published maps and institutional affiliations.

Copyright: (c) 2021 by the authors. Licensee MDPI, Basel, Switzerland. This article is an open access article distributed under the terms and conditions of the Creative Commons Attribution (CC BY) license (https:// creativecommons.org/licenses/by/ $4.0 /)$.

\section{Metabolic Hormones Modulate Macrophage Inflammatory Responses \\ 1.1. Introduction}

Hormones are ubiquitous chemical messengers that mediate physiological communication. Classically, they are defined as being produced by specialised cells within endocrine glands and released into the bloodstream in which they are carried until they reach their target cells. A tightly controlled spatiotemporal network of hormone signals mediates crosstalk within and between different organ systems to maintain healthy homeostasis. Disturbances to this network as a result of diet, lifestyle, or environmental factors can lead to obesity and diseases such as cancer [1]. Increased adiposity in obese individuals leads to dysregulation of many hormones [2] including those whose functions are to coordinate metabolism (which we refer to as 'metabolic hormones') (Table 1 and Figure 1A). Macrophages are phagocytotic leukocytes that play an important role in inflammation and have established roles in metabolic diseases [3] and cancer progression [4,5]. Recent evidence suggests many metabolic hormones play additional roles in inflammation, which includes modulating macrophage inflammatory responses. 
Table 1. Summary of the metabolic hormones reviewed.

\begin{tabular}{|c|c|c|c|c|c|}
\hline Hormone & Trigger & Origins & Metabolic Target & Receptor & $\begin{array}{l}\text { Primary Metabolic } \\
\text { Functions }\end{array}$ \\
\hline CCK & Fatty acids, proteins & Small intestine I-cells & Pancreas & CCK1R \& CCK2R & $\begin{array}{l}\text { Stimulates release of digestive } \\
\text { enzymes and insulin }\end{array}$ \\
\hline FABP4 & Lipolysis & $\begin{array}{l}\text { Adipocytes } \\
\text { Macrophages }\end{array}$ & $\begin{array}{l}\text { Adipocytes } \\
\text { Macrophages }\end{array}$ & $\operatorname{PPAR} \gamma$ & $\begin{array}{l}\text { Absorption of fatty acids } \\
\text { M2 macrophage polarisation }\end{array}$ \\
\hline Gastrin & $\begin{array}{l}\text { Food intake } \\
\text { Gastrin releasing } \\
\text { peptide }\end{array}$ & $\begin{array}{l}\text { Stomach G-cells } \\
\text { Duodenum } \\
\text { Pancreas }\end{array}$ & Stomach & CCK1R \& CCK2R & Stomach acid regulation \\
\hline Ghrelin & Food intake & $\begin{array}{l}\text { Stomach } \\
\text { Intestine } \\
\text { Brain } \\
\text { Macrophages }\end{array}$ & $\begin{array}{c}\text { Brain } \\
\text { Adipose tissue }\end{array}$ & GHSR & $\begin{array}{l}\text { Regulates food intake, energy } \\
\text { expenditure, glucose } \\
\text { homeostasis, adiposity }\end{array}$ \\
\hline GIP & Glucose, fatty acids & $\begin{array}{l}\text { K-cells in the } \\
\text { duodenum and } \\
\text { jejunum }\end{array}$ & Pancreatic $\beta$-cells & GIPR & Stimulates insulin release \\
\hline GLP-1 & Hexose, fats & $\begin{array}{l}\text { L-cells of the small } \\
\text { intestine }\end{array}$ & $\begin{array}{c}\text { Pancreatic } \beta \text {-cells } \\
\text { Brain }\end{array}$ & GLP1R & $\begin{array}{l}\text { Stimulates insulin release } \\
\text { Induces satiety }\end{array}$ \\
\hline Insulin & Hyperglycaemia & Pancreatic $\beta$-cells & $\begin{array}{l}\text { Muscle } \\
\text { Liver } \\
\text { Adipose }\end{array}$ & $\begin{array}{l}\text { INSR } \\
\text { IGF1R }\end{array}$ & $\begin{array}{l}\text { Glucose uptake } \\
\text { Inhibition of gluconeogenesis }\end{array}$ \\
\hline IGF-1 & $\begin{array}{l}\text { Growth Hormone } \\
(\mathrm{GH})\end{array}$ & $\begin{array}{c}\text { Liver } \\
\text { Macrophages } \\
\text { Adipocytes }\end{array}$ & $\begin{array}{l}\text { Bones } \\
\text { Smooth muscle } \\
\text { Neurons }\end{array}$ & $\begin{array}{l}\text { IGF1R } \\
\text { INSR }\end{array}$ & $\begin{array}{l}\text { Stimulates bone and tissue } \\
\text { growth }\end{array}$ \\
\hline Leptin & Food intake & Adipocytes & Brain & OBR & Regulation of food intake \\
\hline NPY & $\begin{array}{c}\text { Food intake } \\
\text { (High levels of } \\
\text { dietary fat and sugar) }\end{array}$ & Central nervous system & $\begin{array}{c}\text { Central and } \\
\text { peripheral nervous } \\
\text { systems }\end{array}$ & $\begin{array}{l}\text { NPY Receptors } \\
\text { (GPCRs) }\end{array}$ & Regulation of food intake \\
\hline PYY & $\begin{array}{l}\text { Amino acids } \\
\text { Short-chain fatty } \\
\text { acids }\end{array}$ & $\begin{array}{l}\text { L-cells of the ileum and } \\
\text { colon }\end{array}$ & $\begin{array}{c}\text { Central and } \\
\text { peripheral nervous } \\
\text { systems }\end{array}$ & $\begin{array}{l}\text { PYY Receptors } \\
\text { (GPCRs) }\end{array}$ & $\begin{array}{l}\text { Gastric emptying } \\
\text { Gut motility }\end{array}$ \\
\hline Estrogen & $\begin{array}{l}\text { Luteinizing hormone } \\
\text { (LH) }\end{array}$ & $\begin{array}{l}\text { Gonads, adipose tissue, } \\
\text { bone, skin, liver \& } \\
\text { brain }\end{array}$ & Systemic & $\begin{array}{c}\mathrm{ER} \alpha \\
\mathrm{Er} \beta \\
\text { GPER }\end{array}$ & $\begin{array}{c}\text { Primary female sex hormone } \\
\text { Fat distribution } \\
\text { Metabolism }\end{array}$ \\
\hline Testosterone & $\begin{array}{l}\text { Luteinizing hormone } \\
\text { (LH) }\end{array}$ & $\begin{array}{l}\text { Leydig cells of the testis } \\
\text { \& adrenal glands }\end{array}$ & Systemic & $\mathrm{AR}$ & $\begin{array}{l}\text { Primary male sex hormone } \\
\text { Fat distribution } \\
\text { Muscle mass }\end{array}$ \\
\hline
\end{tabular}

A

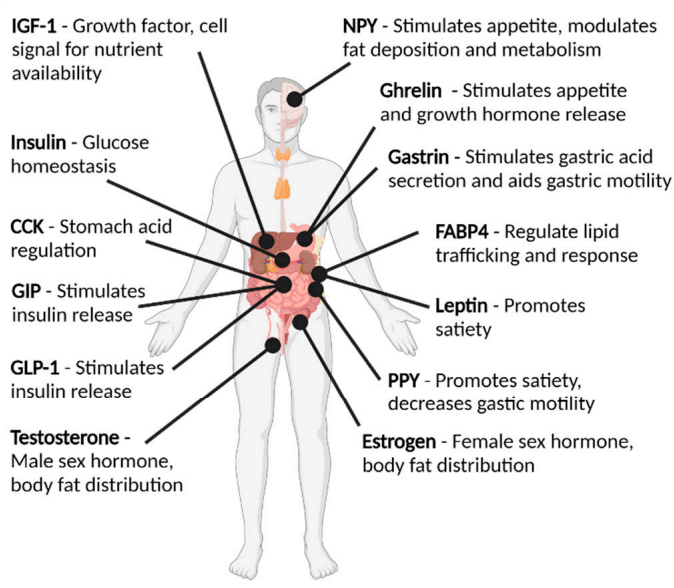

B

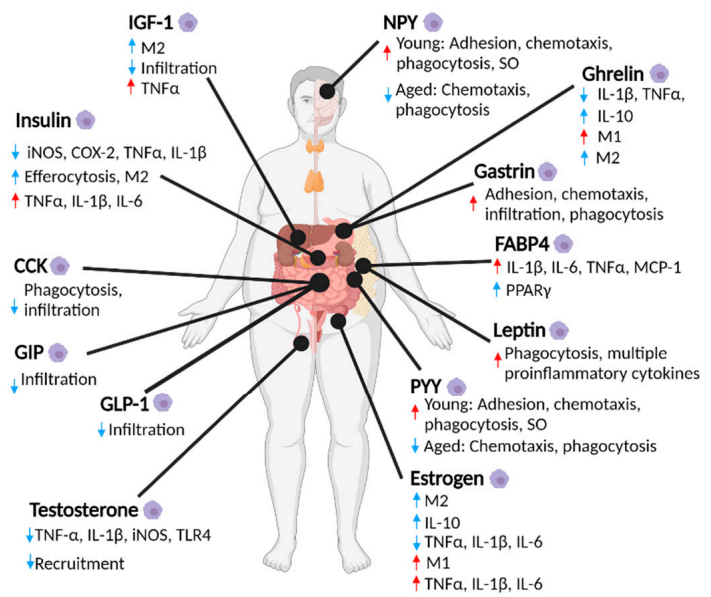

Figure 1. Schematic summarising (A) the classical functions of metabolic hormones in a healthy individual, and (B) how these hormones can modulate macrophage inflammatory responses when potentially dysregulated in an obese state. Red arrows indicate proinflammatory actions, blue arrows indicate anti-inflammatory actions. This figure was created with Biorender.com. 
This review highlights key classical metabolic hormones (Table 1 and Figure 1A) that become dysregulated in obesity and cancer and discusses their emerging roles in macrophage inflammatory responses (Figure 1B)—which have the potential to influence cancer progression (Figure 2). In this review, we have also included the sex hormones estrogen and testosterone due to their important direct and indirect roles in metabolism through their influence on body fat distribution and effect on cancer sexual dimorphism (Table 1 and Figure 1A).

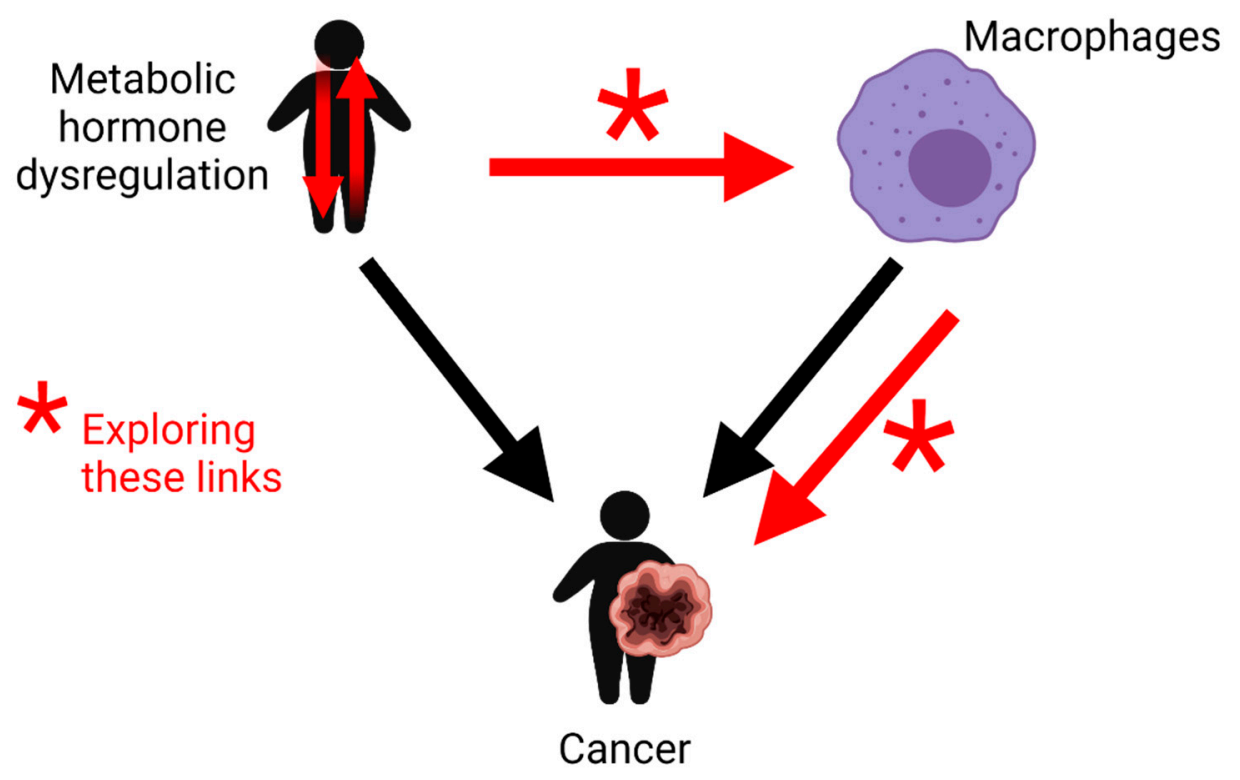

Figure 2. Schematic illustrating the links this review will explore (red arrows) between potential metabolic hormone dysregulation, macrophage inflammatory responses and cancer development. This figure was created with Biorender.com.

\subsection{The Role of Macrophages in Cancer Development}

Macrophages are phagocytic cells of the hematopoietic lineage that play a central role in the innate immune response and also have established roles in metabolic diseases [3] and cancer initiation, malignancy, and metastasis [4,5]. Macrophages pervade almost every organ system and can exhibit a wide range of phenotypes depending on their particular microenvironment. During the last two decades, the conceptual framework for macrophage activation has evolved. Initially, macrophages were polarized into classically (M1) or alternatively (M2) activated cells [6] representing two polar inflammatory or anti-inflammatory extremes, respectively. The M1 vs. M2 model has been useful in describing immune responses during acute infections, allergies, asthma, and obesity [7]. However, observations from macrophages involved in chronic inflammation such as type 2 diabetes and cancer strongly suggest a much broader, context-dependent transcriptional repertoire in which macrophages adopt a spectrum of phenotypes that go beyond the rigid M1/M2 nomenclature [6,8]. Recent transcriptomics studies have now made considerable contributions to a better understanding of immune cell function and regulation; there are now at least nine distinct macrophage activation programs recognised [8], and within these programs, there are multiple unique gene expression signatures that enable macrophages to exist in a spectrum of activation states [8]. Nevertheless, to better compare the findings of the literature referenced within this review and in the absence of a framework to more accurately reflect the new macrophage phenotype spectrum, we will continue to use the M1/M2 convention as appropriate.

Tissue-resident macrophages may originate from yolk sac-derived erythromyeloid progenitors or circulating monocytes from bone marrow resident haematopoietic stem cells [9]. Tissue-resident macrophages display specific characteristics local to the tissues they reside in [10], which influence their function and hence their effect on their surround- 
ing tissues. Macrophages can be highly influential on tumour development through the induction of inflammation, stimulation of neoangiogenesis, immune suppression or induction of metastasis. Macrophages that populate a tumour's surrounding environment (the tumour microenvironment (TME)) are referred to as tumour-associated macrophages (TAMs); we direct the reader to the very recent review by Cendrowicz et al. [11] for a detailed description of the contribution of TAMs to the formation and development of tumours. Both clinical and experimental evidence has found that a high density of TAMs within a TME is strongly correlated with poor prognosis and reduced survival in a number of cancer types [12]. While TAMs have been found to display a wide spectrum of phenotypes, the majority are reported to have M2-like immunosuppressive properties due to the higher expression of IL-10 and TGF- $\beta$ in TMEs, which is thought to help tumours evade cancer cell elimination by the immune system [12]. In contrast, pro-inflammatory M1-like TAMs are thought to establish a tumour-inhibiting phenotype by allowing tumoricidal activity to resume through the reversal of immunosuppressive mechanisms. Macrophages express hormone receptors [13] and because of the systemic nature of these metabolic hormones and the significant role that macrophages play in tumour development, the potential of dysregulated hormone levels to modulate tumour microenvironments and hence macrophage inflammatory responses may be significant.

\section{Metabolic Hormones Play Roles in Modulating Macrophage Inflammatory Responses}

\subsection{Cholecystokinin (CCK)}

\subsubsection{Origin and Function}

The peptide hormone Cholecystokinin (CCK) is well-established as being a metabolic hormone secreted from I cells of the small intestine when high levels of dietary fatty acids or proteins are detected [14]. CCK regulates digestion by stimulating the release of digestive enzymes and insulin from the pancreas and mediates satiety by binding to CCK receptors in the vagal afferent neurons of the gut-brain axis [15]. However, CCK is also a neurotransmitter, growth factor and anti-inflammatory cytokine expressed as multiple different bioactive peptides by neurons, endocrine, and epithelial cells (recently reviewed in [16]). The effects of CCK are mediated through two types of receptors; CCK1R and CCK2R $[17,18]$. CCK1R is mainly located in peripheral tissues and shows higher selectivity for CCK than CCK2R [19].

\subsubsection{CCK and Cancer Association}

Diets rich in long-chain saturated fatty acids lead to the overexpression of CCK which alongside obesity, is a significant risk factor for pancreatic cancer $[20,21]$ and elevated CCK levels are also associated with the development of pancreatic metastases in mice [22]. CCK receptors can be over-expressed in a range of human cancers including stomach, pancreas, colon, rectum, oesophagus, lung, and liver [23,24].

\subsubsection{CCK Modulates Macrophage Inflammatory Responses}

Studies to date indicate an anti-inflammatory role of CCK in several diseases and animal models of disease [25-32] demonstrated by ablation of CCK or CCKR, or treatment with CCKR antagonists which exert pro-inflammatory effects [27,30,33]. Both CCK receptors are expressed in macrophages $[34,35]$ although CCK-1R is the predominant mediator of CCK's immunomodulatory effects [36]. The CCK-8 isoform negatively modulates macrophage functions such as phagocytosis and tissue infiltration $[26,27,37]$ and inhibits inflammatory response through downregulation of CD68, ICAM-1, TGF- $\beta$, and TNF $\alpha$ gene expression and inhibition of NF- $\mathrm{kB}$ activity [30]. In peritoneal and pulmonary interstitial macrophages, CCK- 8 treatment blocks LPS-induced IL- $1 \beta$ production, reduces nitric oxide production and attenuates iNOS and TNF $\alpha$ mRNA expression $[29,36,38]$. These studies indicate the mechanism through which CCK exerts anti-inflammatory effects is through modulation of p38 and NF- $\mathrm{KB}$ activity via inhibition of PKC and activation of the CAMP- 
PKA pathway [29,30,36-38]. It is therefore possible that the pancreatic tumour growth associated with CCK expression can be attributed to the capacity of CCK to promote macrophages to adopt a pro-tumour, M2 phenotype.

\subsection{FABP4}

\subsubsection{Origin and Function}

Fatty acid-binding proteins (FABP) are at least a nine-member family of 14-15 kDa proteins that facilitate the absorption and utilisation of water-insoluble dietary long-chain fatty acids [39]. The different family members are uniquely expressed in distinct tissues involved in active lipid metabolism, including adipocyte FABP (known as FABP4). FABP4 is highly expressed by mature adipocytes $[40,41]$ and macrophages $[42,43]$ and the major regulator of FABP4 signalling is peroxisome proliferator-activated receptor (PPAR) $\gamma[43,44]$.

\subsubsection{FABP4 and Cancer Association}

Evidence suggests that FABP4 levels impact diseases ranging from metabolic syndrome, type two diabetes, atherosclerosis [45-48] and various forms of cancer including breast, liver, colon, and ovarian [49-52]. FABP4 has been shown to promote tumour progression via enhancement of new blood vessel formation and tumour growth mediated by its effects on adipocytes and tumour cells [53,54]. However, in contrast to these findings, decreased levels of FABP4 have also been associated with hepatocellular carcinoma tumours and FABP4 was shown to suppress proliferation and invasion of hepatocellular carcinoma cells [50], suggesting that the influence of FABP4 on cancer development and progression may depend on the cancer type and microenvironment situation.

\subsubsection{FABP4 Modulates Macrophage Inflammatory Responses}

FAPB4 is expressed in macrophages [42,43], with substantial crosstalk between macrophages and adipocytes occurring upon inflammatory activation [55]. The regulation of FABP4 signalling by PPAR $\gamma$ was demonstrated by Garin-Shkolnik et al. through FABP4 triggering proteasomal degradation of PPAR $\gamma$ which inhibited PPAR $\gamma$-related functions [56] including its role in inhibiting the expression of inflammatory cytokines and directing the differentiation of immune cells towards anti-inflammatory phenotypes [57,58]. As PPAR $\gamma$ interferes with NF- $\mathrm{KB}, \mathrm{AP}-1$ and STAT transcriptional activity [58,59], it inhibits the upregulation of pro-inflammatory genes, such as IL- $1 \beta$, IL- 6 , and TNF $\alpha$. The repression of PPAR $\gamma$ is therefore associated with the initiation of inflammatory pathways and impaired alternative M2 macrophage activation [60]. Indeed, FABP4-deficient macrophages are seen to have reduced basal and stimulated expression of pro-inflammatory cytokines including TNF $\alpha$, IL-1 $\beta$, MCP-1, and IL- 6 due to decreased/NF- $\mathrm{kB}$ activity and deficient activation-induced expression of iNOS [42,61,62]. Additionally, FABP4 is shown to exacerbate LPS-induced inflammation by forming a positive feedback loop with the JNK signalling cascade [63], and subsequently influences the production of inflammatory cytokines. However, in contrast, some studies have suggested that FABP4 may enhance the activities of PPAR $\gamma$ during the differentiation of macrophages, providing a positive feedback loop between the two proteins [64]. These-conflicting findings have been suggested to arise from FABP4 exerting a concentration dependent effect on PPAR $\gamma$ regulation. Other regulators that have been seen to induce FABP4 expression in macrophages include rapamycin [65], which can increase the expression of genes involved in cholesterol transport and triglyceride synthesis. Notably, intracellular FABP4 has been observed to enhance pro-tumour macrophage function. FABP4 is highly expressed in a small subset of TAMs of the CD11b + F4/80 + MHCII - Ly6C - CD11c - phenotype [49]. FABP4-positive TAMs accumulate in late-stage mammary tumours, promoting their growth through the enhancing effect FABP4 has on NF- $\mathrm{kB}$ expression, thereby increasing the secretion of pro-tumour IL-6 signalling. Indeed, genetic ablation or chemical inhibition of FABP4 in TAMs has been shown to suppress mammary tumour growth [49]. 


\subsection{Gastrin}

\subsubsection{Origin and Function}

Gastrin is a stomach acid secretion-regulating peptide hormone produced by endocrine G-/gastrin cells in the pyloric antrum of the stomach, duodenum, and pancreas. The gastrin gene in humans encodes a 101 amino-acid precursor peptide, which is subsequently cleaved to generate progastrin before being cleaved once again to form gastrin itself-the dominant forms of which in human plasma are gastrin-34 and gastrin-17 [66]. Once synthesised, gastrin peptides are stored in the basal part of the G-cells until they are released either in response to food intake or induced by the neurotransmitter gastrinreleasing peptide (GRP) acting on basolateral receptors in the G cells. Once released, gastrin modulates its effects through the CCK receptors; CCK1R and CCK2R, the latter of which has a higher affinity for gastrin.

\subsubsection{Gastrin and Cancer Association}

Gastrin has been observed to directly induce the expression of pro-inflammatory molecules such as IL-8, CINC-1 and the enzyme COX-2 in gastric epithelial cells $[67,68]$. COX enzymes are known to catalyse the synthesis of prostaglandins, a pathway shown to play an important role in cancers. Furthermore, COX-2 inhibition has been shown to suppress cell proliferation and induce apoptosis in various gastrointestinal cancer cell lines in vitro [69]. The pro-inflammatory effect of gastrin has also been hypothesised to play a role in cancer initiation through its association with $H$. pylori which is known to induce gastric cancer development and progression [70]. Gastrin-releasing peptide (GRP) and its receptor (GRPR) have also been linked to cancerous malignancies [71] and GRPR has been shown to induce the release of IL-8 and vascular growth factor in the case in human prostate cancer cell lines [72].

\subsubsection{Gastrin Modulates Macrophage Inflammatory Responses}

Both CCK1R and CCK2R have been identified in an array of human leukocyte cell types, including lamina propria macrophages [73], peripheral blood mononucleocytes [34,74], circulating polymorphonuclear leukocytes (PMNs) [75] and also PMNs found within human malignant colorectal tumours [76]. One of the first links between gastrin and macrophages was provided by Okahata et al. in 1985 when they demonstrated that gastrin treatment resulted in increased immunoreactivity in pure populations of human PMNs [77] and further in vitro studies have shown that murine macrophages and human PMNs treated with gastrin induces chemotaxis and increases adherence and phagocytosis $[78,79]$. Alvarez et al. also noted that gastrin treatment increased leukocyte rolling and adhesion, decreased rolling velocity and increased leukocyte infiltration into the interstitium and as CCK2R, but not CCK1R antagonists abrogated these effects it is thought that CCK2R mediates gastrin's inflammatory effects [80]. The gastrin receptor CCK2R has been further implicated in the pro-inflammatory response due to its promoter containing an IFN- $\gamma$ regulatory site [81]. In addition to these direct effects on macrophages, gastrin may modulate their function by acting on the surrounding tissue. Gastrin, mediated by CCK2R, is reported to induce the release of IL-8 from human endothelial cells and increase the synthesis of the adhesion molecules VCAM-1 and P-selectin, resulting in increased adhesivity for human mononuclear leukocytes [82,83].

\subsection{Ghrelin}

\subsubsection{Origin and Function}

Ghrelin is an orexigenic hormone primarily produced by enteroendocrine cells in the stomach. Although its highest levels are found in the stomach and intestine [84], it is also expressed in the brain [85] and by macrophages [86]. Ghrelin has been demonstrated to regulate food intake, energy expenditure, glucose homeostasis, adiposity, body weight, inflammation, and growth hormone (GH) secretion [87]. There are two isoforms of ghrelin as a result of post-translational modifications; desacyl-ghrelin and acyl-ghrelin. The 
desacetylated form of ghrelin, desacyl-ghrelin, can undergo octanoylation performed by ghrelin O-acyltransferase (GOAT) to become acyl-ghrelin, which is also referred to as the active although least abundant form of the hormone. Ghrelin's function is mediated by the Growth Hormone Secretagogue Receptors (GHSR). The acyl-ghrelin form can bind to GHSR $1 \alpha$ and GHSR1 $\beta$ forms [88-90]. These receptors are highly expressed in the brain, poorly expressed in adipose tissue, and are localized within several immune cell types including monocytes and macrophages [86,90-92]. Ghrelin is down-regulated in obese patients and up-regulated under conditions of negative energy balance in humans and mice $[93,94]$.

\subsubsection{Ghrelin and Cancer Association}

Ghrelin regulates several processes related to cancer progression recently reviewed in [95] including cellular proliferation, inflammation, and energy homeostasis. However, the precise relationship between the ghrelin axis and cancer development remains unclear and controversial due to conflicting results observed between in vitro [96] studies involving a range of tumour cells lines and clinical studies [97]. Several recent attempts have been made recently to standardise these findings $[95,98]$ leading to the hypothesis that the systemic nature of ghrelin signalling may contribute to confounding local factors that make delineating ghrelin's direct role in cancer progression complex. Furthermore, experimental variations such as different cell lines and dosages used, add additional difficulties to interpreting the effects of ghrelin from these in vitro studies. In vivo animal and human studies have also revealed that ghrelin expression is often downregulated in cancer tissues and blood plasma while having no clear correlation with tumour development [99].

\subsubsection{Ghrelin Modulates Macrophage Inflammatory Responses}

In macrophages the effects of ghrelin are complex; exogenous ghrelin treatment in the RAW264.7 macrophage cell line has been shown to inhibit LPS-induced production of pro-inflammatory cytokines IL-1 $\beta, \mathrm{TNF} \alpha$ and promote the release of the anti-inflammatory marker IL-10 [86]. However, in contrast, acyl ghrelin treatment in RAW264.7 macrophages promoted macrophage polarization to M1 under an inflammatory state by enhancing the effect of LPS and weakening the effect of IL-4 [100]. Although both studies used the same in vitro model, the doses of LPS used and the incubation time differed between the two studies $(1000 \mathrm{ng} / \mathrm{mL}$ vs. $10 \mathrm{ng} / \mathrm{mL}$ ) which may explain the contradictory results. In vivo work [101] has demonstrated that GHSR knockout, in aged mice, promotes macrophage phenotypic shift towards an anti-inflammatory M2 state. Yet, in contradiction to these results, a separate study showed GHSR knockout in mice fed a high-fat diet, to have a beneficial effect on adipose tissue [100]. The mice had reduced adipose tissue inflammation, decreased macrophage infiltration, and improved insulin sensitivity. Moreover, macrophages were polarized into an M2 type. Several additional studies show ghrelin to be anti-inflammatory [102-105], thought to be the result of JNK inhibition and activation of the Wnt/ $\beta$-catenin pathway $[92,106,107]$. Recently $[108,109]$, the effects of ghrelin, and ghrelin analogue hexarelin, on macrophages induced with oxidised-LDL (ox-LDL) and observed inhibition of LOX1 gene expression as a result of reduced ox-LDL uptake and decreased TNF $\alpha$ and IL- 6 release. Similar protective effects of ghrelin have been demonstrated in alveolar macrophages induced with LPS where ghrelin treatment was able to reduce the level of IL-1 $\beta$, TNF $\alpha$, and IL-6, as well as decreasing iNOS and Akt activity. LOX-1-NF-kB and NF- $\mathrm{kB} / \mathrm{iNOS}$ pathways or Akt signalling are the pathways suggested to mediate these anti-inflammatory effects [108-110].

\subsection{Incretins}

\subsubsection{Origin and Function}

The incretin hormones; glucose-dependent insulinotropic polypeptide (GIP, also known as gastric inhibitory polypeptide) and glucagon-like polypeptide-1 (GLP-1) are secreted by the small bowel in response to nutrients and stimulate the release of insulin 
from pancreatic $\beta$ cells. Both GIP and GLP-1 are rapidly degraded by dipeptidyl peptidase 4. GIP is a 42-amino acid peptide secreted by enteroendocrine $\mathrm{K}$ cells of the small intestine. Its action is mediated by gastric inhibitory peptide receptor (GIPR), which is expressed mainly in the pancreas but can also be found in other tissues and immune cells [111,112]. GLP-1 is expressed in L cells of the small and large intestines [113] and is derived from the proglucagon gene [114]. GLP-1 action is mediated by the glucagon-like polypeptide-1 receptor GLP1R [115].

\subsubsection{Incretins and Cancer Association}

GLP1R is reportedly overexpressed in many tumour cell types [116]. However, the role of GLP1R overexpression in neoplasia remains unknown Incretin mimetic drugs such as exenatide and liraglutide are powerful and widely used treatments for type II diabetes [117]. Like GLP-1 and GIP, they bind to GLP1R on the pancreatic $\beta$ cells to stimulate insulin secretion. Exenatide has been shown to promote apoptosis in SKOV-3 and CAOV-3 human ovarian cancer cell lines and reduce the production of the pro-metastatic adhesion molecules ICAM-1 and VCAM-1 by TNF $\alpha$ stimulated vascular endothelial cells [118]. Similar observations have been made in studies using breast [119], colon [120], and ovarian [121] cancer cell lines, likely due to the inhibition of the PI3K/Akt signaling pathway by exenatide. However, whilst concerns have been raised over the safety of incretin-based treatments for those living with both cancer and diabetes meta-analysis of clinical data has not revealed any association between the development of lung [122], gastrointestinal [123] or pancreatic [124] cancer and the prescriptions of the incretin analogues.

\subsubsection{Incretins Modulate Macrophage Inflammatory Responses}

Incretins have demonstrated overall metabolic benefits and anti-inflammatory effects in macrophages in the context of inflammation-mediated obesity [125]. Treatment with GLP1, or GLP1 agonist, improves insulin sensitivity, glucose, and insulin tolerance, normalises glycemia, and reduces fat mass, adipocyte size and macrophage number in adipose tissue as a result of macrophage infiltration inhibition [126-128]. In vitro studies on several different models of macrophage cells (peritoneal macrophages, LPS treated RAW264.7 cells and adipose tissue macrophages (ATM)) have consistently shown the anti-inflammatory effect of GLP1 and its agonists. These studies have shown a decrease in pro-inflammatory markers (iNOS, IL-1 $\beta$, IL-6, TNF $\alpha$ and MCP1, MMP2, MMP9, ROS) [129-131]) while increasing anti-inflammatory markers (IL-10, mannose receptor-1 (MRC-1), macrophage galectin-1 (MGL-1), arginine-1 (ARG-1)) [128-130,132], PGE2 and COX2 mRNA and COX2 protein level [129]. Studies have demonstrated these effects to be mediated through JNK inhibition, STAT3 activation [132,133], and also the cAMP/PKA/NF- $\mathrm{KB}$ signalling pathway $[126,128-130,132]$. In vitro, GLP1 has been shown to decrease cell migration through its reduction of MCP-1 and MMP-9 activity which may be mediated by the inhibition of Nf-KB, JNK, ERK, and p38 in LPS activated macrophages [134,135]. GLP1 and GIP inhibitor DPP4 (also known as CD26) enhances the expression of TNF $\alpha$ and IL-6 mRNA and protein in THP-1 cells [136] while GIP prevents proinflammatory macrophage activation leading to reduced LPS-induced IL-6 secretion [134].

\subsection{Insulin}

\subsubsection{Origin and Function}

Insulin is an anabolic hormone secreted by the $\beta$ cells of the pancreas. Insulin regulates glucose homeostasis, lipid metabolism [137] and cell growth [138]. The effects of insulin are mediated through the insulin receptor (INSR) $[139,140]$ and the insulin-like growth factor 1 receptor (IGF-1R) [141]. Upon binding to its receptor, insulin activates two major downstream pathways, the PI3K pathway which mediates its metabolic effects [142] including the translocation of GLUT4 in metabolic tissues such as muscle and adipose, and the MAPK kinase pathway [143] which regulates mitogenesis and growth. The insulin receptor has also been shown to act directly as a transcription factor [144], which may 
illuminate previously unrecognised mechanisms of the long-term effects of insulin normal physiology and disease.

\subsubsection{Insulin and Cancer Association}

Metabolic diseases such as obesity and type 2 diabetes that are characterised by hyperinsulinemia are associated with the development of several types of cancer including colon, breast, endometrium, oesophagus, kidney, liver, and pancreas [145-148]. Insulin can promote cancer through its mitogenic actions [149] and the INSR is often overexpressed in tumour cells [150-152]. More recently, a new mechanism has been demonstrated showing that hyperinsulinemia promotes epithelial tumourigenesis by abrogating cell competition [153].

\subsubsection{Insulin Modulates Macrophage Inflammatory Responses}

Macrophages express insulin receptors [154] and intracellular signalling machinery. Existing reports demonstrate diverse effects that include promoting pro-inflammatory responses through increasing phagocytosis [155], and TNF $\alpha$ production [156]. However, other studies report an anti-inflammatory response involving decreased apoptosis [157] and decreased pro-inflammatory cytokine production $[158,159]$. Discrepancies may be due to inconsistencies in the macrophage cells used (mouse [160] or human cell lines [156,157]; mouse tissue macrophages [161] or human peripheral cells [162]), and lack of consistency of insulin concentration and duration used. We would direct the reader to the very recent review [163] detailing insulin's inflammatory and anti-inflammatory effects on macrophages.

\subsection{Insulin-Like Growth Factor-1}

\subsubsection{Origin and Function}

Insulin-Like growth factor-1 (IGF-1) is a polypeptide hormone mainly produced in the liver where growth hormone (GH) binds to its receptor to drive most of the IGF1 synthesis [164]. IGF1R is also expressed in adipocytes [165] endothelial cells and macrophages [166,167]. Its actions can be endocrine, paracrine, or autocrine and are mediated by the tyrosine kinase receptor IGF-1R. IGF-1 is involved in growth, regulation of metabolism, and inflammation [168]. Structural similarities with insulin enable IGF-1 to bind to both IGF-1 and insulin receptors [169]. IGF-1 signal transduction requires insulin receptor substrates (IRS) [170] and involves the downstream phosphoinositide-3 kinase (PI3-K) and MAPK activation pathways [171].

\subsubsection{IGF-1 and Cancer Association}

Above normal levels of circulating IGF-1 are associated with an elevated risk of developing several primary cancer types including colorectal [172] and breast [173]. IGF-1 has been demonstrated to enable tumour growth by preventing apoptosis through the induction of the PI3K and MAPK signalling cascades [174]. Furthermore, IGF-1 has been shown to increase the migratory and proliferative capabilities of IGF-1R-overexpressing HCT116 colon cancer cells, leading to metastases in mice transfected with these cells [175]. Finally, IGF-1R is known to be overexpressed by cancer cells contributing further to the malignant phenotype [176].

\subsubsection{IGF-1 Modulates Macrophage Inflammatory Responses}

Macrophages polarized into an anti-inflammatory M2 subtype express high levels of IGF-1 $[166,177,178]$. A recent study assessing IGF-1 implication in the development of obesity [166] using mice with myeloid cell-specific ablation of IGF-1R and challenged with a high-fat diet showed increased macrophage infiltration in adipose tissue leading to insulin resistance and also suggested an anti-inflammatory role for IGF-1 on macrophages. In contrast, however, other studies have reported IGF-1 to have a pro-inflammatory effect on macrophages; IGF-1 treatment on murine macrophages has been shown to increase production and expression of TNF $\alpha$ mediated by IGF-1R and tyrosine kinase factor activation [179], 
and to stimulate LDL uptake and cholesterol esterification [180]. Ablation of IGF-1R in macrophages was also seen to significantly decrease NLRP3 inflammasome-dependent caspase- 1 and IL-1 $\beta$ activation when induced by ageing-relevant damage-associated molecular patterns (DAMPs) [181].

\subsection{Leptin}

\subsubsection{Origin and Function}

Leptin is a pleiotropic peptide hormone encoded by the $o b$ gene and secreted by adipose tissue in proportion to its abundance [182]. It was first reported to control food intake and body weight through anorexigenic effects in the brain $[183,184]$. Leptin receptors (known as LEPR or OBR) are class I cytokine receptors expressed in many cell types, including macrophages [185] where Ob-Rb is the most well-characterized isoform [186,187].

\subsubsection{Leptin and Cancer Association}

The role of the leptin-Ob-Rb signalling axis in cancer development is well documented with both leptin and OBR becoming overexpressed in several cancer types including head and neck, pancreatic, and breast cancer [188]. Leptin signalling has been implicated as a driver of angiogenesis in colorectal cancer [189] and glioblastoma [190], resulting in metastasis and tumour growth. Leptin increases the expression of inflammatory cytokines such as TNF $\alpha$ and IL- $1 \beta$ which contributes to tumour-associated inflammation and subsequently, immunosuppression of tumouricidal CD8+ cytotoxic T cells in breast cancer [191]. Furthermore, leptin is known to have direct effects on ovarian cancer cell proliferation and growth by activating the PI3K/Akt and MEK/ERK1/2 signalling pathways [192]. Obesity is also associated with elevated serum leptin levels, with many obese individuals experiencing 'leptin resistance' in which leptin is no longer able to effectively regulate food intake. The exact reason for the upregulation of leptin during obesity is unknown, but it has been speculated that leptin may be a critical link between obesity and cancer $[193,194]$.

\subsubsection{Leptin Modulates Macrophage Inflammatory Responses}

Leptin is an adipokine, a member of the superfamily of cytokines [195] and is implicated in inflammation, infection, and immune responses [182]. Genetic abnormalities in leptin or leptin receptors are reported to impair macrophage phagocytosis and promote proinflammatory cytokines production, while leptin treatment increases both [196]. Similarly, in vitro studies on the murine macrophage J774A.1 cell line, human monocyte-enriched mononuclear cells, LPS stimulated Kupffer cells and human adipose macrophages have shown that leptin can stimulate the phagocytotic activity of macrophages [197] and the proliferation and activation of monocytes [198]. In addition, leptin may stimulate production of proinflammatory cytokines TNF $\alpha$, resistin, IL-6, and IL-1 $\beta$, IL-1Ra, IL-10, MCP-1, and MIP-1 $\alpha$ and enhance CC-chemokine ligand expression [199-201]. These effects might be mediated through activation of a JAK2-STAT3 pathway [199] and may also activate ERK1/2, P8 MAPK, JNK, AMPK, PKC and PI3K/Akt pathways [185,202-205].

\subsection{Neuropeptide $Y(N P Y)$ and Peptide $Y Y(P Y Y)$}

\subsubsection{Origin and Function}

Both NPY and PYY belong to a family of neuropeptides bearing a close resemblance to each other, consisting of 36-amino acids with a unique hairpin turn called the PP-fold [206]. NPY is highly abundant and is found in all levels of the gut-brain axis as well as being highly expressed in the central nervous system where it is widely known for its activity as a regulator of food intake and energy balance [207]. PYY is almost exclusively associated with the digestive system and is predominantly expressed in L cells in the ileal and colonic mucosa and released into the bloodstream post-prandially in proportion to calorie intake [207-210]. NPY and PYY peptides can also be truncated, yielding the fragments NPY(3-36) and PYY(3-36) [211]. In humans, NPY and PYY's functions are mediated by diverse G-protein coupled Y receptor subtypes, of which seven have been noted, but only 
four are widely functional (Y1, Y2, Y3 and Y4). NPY(1-36) and PYY(1-36) are thought to bind to all the receptors with an equal affinity, whilst NPY(3-36) and PYY(3-36) exhibit the highest affinity for Y2 [212-214].

\subsubsection{NPY and PYY and Cancer Association}

Investigation of PYY and NPY, have collectively revealed that they are implicated in a variety of inflammatory disorders, such as autoimmune diseases, asthma, atherosclerosis, and cancer [215-217]. Y receptors have recently attracted attention due to their overexpression in various human cancers, including breast carcinomas and neuroblastomas, creating interest in their use as a possible target for cancer imaging and therapy [218]. The $Y$ receptors mediate tumour development through their direct effect on cancer and endothelial cells promoting tumour cell proliferation, survival, and migration, as well as angiogenesis) [219].

\subsubsection{NPY and PYY Modulate Macrophage Inflammatory Responses}

In macrophages, neuropeptides have been found to exert varying effects depending on the age of the subject. In one of the first studies examining their role in macrophage function, both NPY and PYY were found to increase adhesion, chemotaxis, and phagocytosis in murine peritoneal macrophages, as well as increasing the production of superoxide anions in young adult mice [220]. The authors noted that this effect was produced through the stimulation of PKC due to a significant increase in its activation following NPY and PYY treatment. However, in more aged mice, this effect was potentiated, with chemotaxis and phagocytosis being decreased. These changes have been hypothesised to be dependent on the activity of dipeptidyl peptidase 4 , an enzyme that terminates the activity of neuropeptides on the Y1 receptor subtype and whose activity is seen to change with age [221]. This age-dependent impact in modulating the immune response was also found to be true concerning PYY and NPY acting via Y1 receptors to potentiate nitric oxide production in rat peritoneal macrophages, with production being suppressed in older rat cells [222]. Y receptors are known to be widely expressed in immune cells, particularly $\mathrm{Y} 1$, which has been found in almost every type of immune cell [223].

The expression of $Y$ receptors is also significantly upregulated after antigen or inflammatory stimulation [224-226]. Studies have also demonstrated the ability of neuropeptides to modulate macrophage cytokine secretion. However, contradictory results have been found. Y1 ablation in macrophages has been seen to lead to an increased pro-inflammatory phenotype displaying increased inflammatory response and exacerbated secretion of MCP1 and TNF $\alpha$, and a similar response was seen in macrophages isolated from double NPY and PYY knockout mice, suggesting an anti-inflammatory role [227]. Additionally, NPY was shown to decrease the production of TNF $\alpha$ and IL-1 $\beta$ following LPS treatment $[228,229]$ and increase that of TGF $\beta 1$ in RAW264.7 cells [230]. In contrast, other studies have reported NPY to increase the production of pro-inflammatory mediators, with NPY being found to significantly increase the expression of $\mathrm{TNF} \alpha, \mathrm{C}$-reactive protein, $\mathrm{MCP}-1$ and reactive oxygen species in RAW264.7 macrophages mediated by the Y1 receptor [231]. NPY has also been shown to stimulate IL-1 $\beta$ secretion in aged animal macrophages [232]. Furthermore, in whole blood cells from healthy subjects, NPY upregulated IL-6, IL-1 $\beta$ and TNF $\alpha$ production [233]. Some suggestions for the observed duality have been differences in species, cell type and cell environment. Additionally, the activation of different $\mathrm{Y}$ receptor types is seen to mediate different effects, and there is evidence that along with $Y 1, Y 4$ and 5 may also play a role in cytokine modulation [227]. A relatively recent study by Cheng et al. found sympathetic stimulation of prostate cancer cells in vitro led to the release of NPY, which in turn was seen to promote myeloid cell trafficking and increased IL6 synthesis in TAMs, promoting tumorigenesis [234]. However, the connections between neuropeptides, immune regulation and cancerous disease have not yet been fully explored, and indeed it may be found that neuropeptides have divergent effects on immune cells in cancer development as observed in their general effects on macrophage function. 


\subsection{Estrogen \\ 2.10.1. Origin and Function}

Estrogens are a class of steroid hormones and are the main female sex hormones, but also play an essential role in both male and female reproductive and non-reproductive processes [235,236]. Estrogen is predominantly synthesised in the gonads in pre-menopausal women; however, non-gonadal sites such as adipose tissue, bone, skin, and the liver and brain can also produce a small but significant amount of estrogen. In humans, estradiol (E2 or 17 $\beta$-estradiol) is the most prevalent and active form of estrogen. Estrogens play an important role in body weight, fat distribution, energy expenditure and metabolism [237].

The effects of estrogen are mediated by two intracellular estrogen receptors (ERs), ER $\alpha$ and ER $\beta$ [238] and by a plasma membrane protein, $G$ protein-coupled estrogen receptor (GPER) [239]. ER $\alpha$ is predominantly expressed in the uterus, ovaries, and breasts, while expression of ER $\beta$ is mainly found in the nervous system, ovaries, cardiovascular system, and the male reproductive system [238]; however, all of these receptors are expressed in both rodent and human macrophages [240-244].

\subsubsection{Estrogen and Cancer Association}

Obesity is often associated with elevated estrogen levels [245] and estrogens are thought to be involved in the sex differences observed to cancer susceptibility [246] and survival rates, with men having higher risk and mortality than women across various cancer types, excluding notable exceptions such as breast cancer $[247,248]$. Various experimental studies have demonstrated ER activity to exert anti-cancer effects recently reviewed in [249]. One example of this is $\mathrm{ER} \beta$ activation shown to suppress the viability and migration of PC-3 and DU145 prostate cancer cell lines by suppressing the inflammatory NF- $\mathrm{B}$ signalling pathway [250]. Another study reported that high levels of ER $\alpha$ expression in cancer-associated fibroblasts suppressed prostate cancer invasion by reducing macrophage migration via its suppression of the chemokine CCL5 [251]. In contrast, other experimental studies implicate estrogen as a potential mediator of tumour immune evasion through its association with the accumulation and increased activity of myeloid-derived suppressor cells, a set of immune cells associated with tumours and treatment resistance [252]. This relationship is thought to arise through $\mathrm{ER} \alpha$ mediated activation of the STAT3 pathway, which has separately been linked to cancer cell survival and the expansion of myeloidderived suppressor cells in cancerous growths [253].

\subsubsection{Estrogen Modulates Macrophage Inflammatory Responses}

Estrogen has been shown to alter macrophage function via its receptors in a variety of ways including their proliferation [254], polarisation and cytokine production [246]. However, it should be noted that RNA transcription levels in resting macrophages indicate that $\mathrm{ER} \alpha$ and GPER are mainly responsible for mediating estrogen action under physiological conditions [255]. The exact splice variants remain controversial, with different variants being reported as the major receptor present in macrophages across various reproductive and non-reproductive tissues and between the sexes [240,244].

During the past decade, the ability of macrophages to proliferate locally has been demonstrated in adipose tissue during obesity [256] and to be an important driver of atherosclerosis development in advanced atherosclerotic plaques [257-260]. A comprehensive description of the genomic responses induced in peritoneal macrophages by a mimicked "estrogen surge" found that estrogen regulates several genes associated with proliferation [254]. However, the exact mechanism by which estrogen is exerting its effect on macrophage proliferation remains unclear. Although estrogen response elements appear to be present in the promoter region of several cell-cycle genes, including Chafa1a, CcnB2 and Wee1, suggesting estrogen may have a direct effect, in vitro assays studying estrogen's effect on peritoneal cells were unable to support macrophage proliferation. It therefore cannot be ruled out that indirect mechanisms involving other peritoneal cells were responsible for the observed increase in proliferative genes observed. 
The study by Pepe et al. [254], also showed that macrophages were initially found to adopt an M2-resembling subtype upon exposure to the mimicked "estrogen surge" with conversion to the pro-resolving phenotype as shown by the induction of the key immunosuppressive cytokine IL-10. Similarly, Campbell et al. [261], demonstrated that treatment with E2 or an ER $\beta$ agonist significantly dampened the $6 \mathrm{~h}$ post-stimulation increase in Nos2 expression usually associated with pro-inflammatory activation of BMDMs upon LPS and IFN- $\gamma$ stimulation [261], suggesting that estrogen induces an inhibitory effect on pro-inflammatory polarisation. In another study, pre-treatment with ER $\alpha$ agonist was seen to strongly induce Arg1 expression (a later marker of alternatively activated, M2-like macrophages) after only $6 \mathrm{~h}$ of stimulation with IL-4, suggesting a direct ER $\alpha$-mediated transcriptional effect. However, in LPS-induced inflammatory conditions, E2 was once again found to influence macrophage polarisation resolution upon inflammatory insult by accelerating the progression of the inflammatory process towards the IL-10 dependent "acquired deactivation" phenotype via SOC3 and STAT3 signalling pathways [262]. In addition, opposing reports regarding estrogen's role in polarisation have also been noted. Yang et al. [263] found estradiol to repress alternative activation in TAMs through the inhibition of the JAK1-STAT6 pathway via ER $\beta$, thereby inhibiting hepatocellular carcinoma tumour growth [263]. In ovariectomised rats, estradiol was found to promote M1-like macrophages through cadherin-11 after the induction of temporomandibular joint inflammation [264]. This discrepancy regarding estrogen's effect on macrophage polarisation state may arise from differences in the specific microenvironment and subsequent ER activation pathways, as a 'yin-yang' relationship has been demonstrated with respect to estrogens' effect on tissues mediated by the activation state of ER $\alpha$ and ER $\beta$. For example, in hormone-related cancers, ER $\alpha$ has been shown to promote proliferative effects, whereas ER $\beta$ is found to inhibit cancer cell proliferation [265].

Seemingly contradictory data also exists regarding estrogen-mediated effects on macrophage cytokine production. One of the ways estrogen's apparent heterogeneous nature appears most evident is in its enhancement or suppression of TNF $\alpha$, IL- 6 and IL-1 $\beta$ gene expression [266-273]. However, this discordance has not been as readily explained by discrepancies in species, estrogen concentration or other culture conditions, leading to the hypothesis that there may be multiple distinct pathways by which estrogen influences cytokine expression. The enhancement or suppression of various cytokines may depend on the specific activation of these distinct pathways in the individual cell context. Alternatively, the increase or decrease in cytokine production seen may be due to certain intrinsic or extrinsic coregulators of estrogen action that are able to change the response, based again on the particular experimental conditions. This discrepancy, particularly with respect to in vivo studies, may also arise in part due to pharmacological differences between hormonal replacement and endogenous estrogen secretion. One example of this is a study in which estrogen's effect on IL-6 concentration in healthy fertile rats did not correspond with that of ovariectomised rats given exogenous E2 [267]. Moreover, there is evidence that estrogen aids tumoral M2-like TAM invasion and promotes macrophage secretion of tumour growth factors, such as VEGF [274]. However, Yang et al. noted opposite findings of estrogen's effect on TAM polarisation [263]. Further studies are therefore needed to fully understand the complex interaction of estrogen and TAMs in context-specific situations.

\subsection{Testosterone}

\subsubsection{Origin and Function}

Testosterone is one of four androgen hormones in humans, the others being dihydrotestosterone (DHT) (a metabolite of testosterone), androstenedione and dehydroepiandrosterone [275]. Although DHT is the most potent of these androgens, testosterone is the principal sexual steroid hormone in men, with the highest concentration in adult male serum [276]. In males, testosterone is primarily synthesized in the testes' Leydig cells and has a characteristic four ring C18 steroid structure [275]. Testosterone is known to exert genomic effects through binding to intracellular androgen receptors (ARs), which are ligand-inducible nuclear tran- 
scription factors [277]. However, rapid physiological responses to testosterone have also been reported. As these occur too quickly to be explained by the classical AR genomic pathway, it is now generally accepted that androgens must also exert non-genomic effects, which are assumed to be mediated through unconventional receptors in the plasma membrane [278].

\subsubsection{Testosterone and Cancer Association}

Obesity is frequently associated with low androgen levels in men [279], whilst women with central obesity have higher total and free testosterone levels than normal-weight women [280]. Cancer sex-disparity in incidence, aggressiveness and prognosis has long been observed and testosterone's modulating effect on the immune system has been investigated in relation to cancer development and progression. In one study of induced thyroid cancer in male mice, gonadectomy led to an upregulation of tumour-suppressor genes, Glipr1 and Sfrp1 [281] suggesting that testosterone promotes thyroid cancer progression through the suppressed expression of these genes. This suppression of Glipr1 is also thought to impact the immune response through its modulation of $\mathrm{Ccl} 5$ secretion, a chemokine that plays important roles in chemotaxis and activation of immune cells. The reduced Ccl5 secretion associated with Glipr1 knockdown led to reduced tumour infiltration by inflammatory macrophage and $\mathrm{CD} 8+\mathrm{T}$ cytotoxic $\mathrm{T}$ cells, thereby aiding tumour immunity, as infiltration by these immune cells is usually associated with reduced tumour growth. Androgen deprivation therapy is also associated with increased infiltration of macrophages and $\mathrm{T}$ lymphocytes in prostate cancer patients [282]. Thus, testosterone's observed cancer-promoting effects may be the result of its immunosuppressive ability; however, further investigation is warranted.

\subsubsection{Testosterone Modulates Macrophage Inflammatory Responses}

Testosterone and other androgens, such as DHT, are generally regarded as immunosuppressors [283]. In line with this, testosterone deficiency has been associated with several disease states involving inflammation, such as cardiovascular disease [284], and various metabolic disorders such as type 2 diabetes mellitus [285]. Furthermore, testosterone replacement therapy has been reported to reduce circulating inflammatory cytokines in hypogonadal men, whilst promoting the secretion of the anti-inflammatory cytokine IL-10 [286].

Specifically, regarding macrophages, several studies suggest that testosterone can modulate macrophage cytokine production and macrophage activity/function. In vitro investigations have shown that androgen treatment diminishes the production of the pro-inflammatory cytokines TNF $\alpha$ and IL-1 $\beta$ in both rodent and human macrophage cell lines [287,288], and in a rat model of experimental autoimmune orchitis, testosterone replacement was found to down-regulate TNF $\alpha$, IL-6 and MCP- 1 mRNA expression in the testis, whilst inhibiting macrophage recruitment (simultaneously increasing the number of immunosuppressive regulatory T-cells) [289]. There is also evidence of testosterone exerting anti-inflammatory effects through regulating macrophage production of reactive oxygen intermediates [290] and nitrites via the inhibition of iNOS [291]. Alongside this, another mechanism by which androgens are thought to regulate macrophage action and exert immunosuppressive effects is through the downregulation of Toll-like receptor 4 (TLR4) [292]. Rettew et al. demonstrated that in vitro testosterone treatment of RAW 264.7 murine macrophage-like cells significantly decreased TLR4 expression, and further evidence of this was seen when castrated animals expressed elevated prostate TLR4 expression compared to intact $[292,293]$. The activation of TLR4 triggers downstream intracellular signalling cascades, including extracellular signal-regulated kinase (ERK), which mediate the secretion of inflammatory cytokines [294]. Therefore, it has been suggested that the TLR4 pathway may represent a key aspect of the increased inflammation seen with testosterone deficiency, and emerging studies have supported this, showing that removal of endogenous testosterone results in elevated ERK activity [295]. 
The exact molecular pathway by which testosterone alters macrophages' immune responsiveness has not yet been fully elucidated. ARs are expressed in human macrophages [296,297]; however, in Friedl et al.'s investigation [291] of testosterone's effect on nitric oxide synthesis, they noted that their observed findings were unlikely to be AR-dependent as the concentrations used in their experiment were much higher than the dissociation constant of the AR c. They therefore suggested that testosterone inhibits iNOS promoter activity via receptor-independent means. Thus, it is likely that both genomic and nongenomic testosterone mediatory pathways are present in macrophages. Indeed, ARs are noted to be associated with infiltrating macrophages in prostate cancer (PCa) development, with Cioni et al. recently demonstrating that AR activity in macrophage-like cells stimulates TREM-1 signalling, thereby promoting PCa-derived cancer cell migration and invasion [298].

\subsection{Future Perspectives}

Metabolic hormones are dysregulated in obesity, and obesity is a significant risk factor for cancer development [1]. Metabolic hormones are systemic in their nature and so have the capability to reach many different cell types including a range of tissueresident macrophages, tumour-associated macrophages and their precursors. As evidenced throughout this review, a growing number of studies have reported new roles of these hormones beyond that of their classical functions of coordinating metabolism. These studies demonstrate a variety of regulatory effects of metabolic hormones on macrophage activity, including polarisation, cytokine secretion, migration, and phagocytosis. Some of the reported effects conflict (Figure 1B), describing pro- or anti-inflammatory actions on macrophages for the same hormone. These studies clearly demonstrate the significant impact that metabolic hormones may play in modulating macrophage function and now pave the way for further research to establish the relevance of these inflammatory-modulating properties in the context of metabolic hormone levels in health and disease.

The complexity of this field can be further appreciated when acknowledging that during chronic diseases such as obesity and cancer, multiple metabolic hormones may be dysregulated simultaneously or at different times during disease progression. These dysregulated hormones may activate multiple intracellular signalling pathways in macrophages, and some of these pathways are shared between hormones (Figure 3).

Identifying the influence that each hormone contributes and/or the net effects of these dysregulated hormones on macrophage responses is the challenge now presented, and this too may be cancer-specific, dependent on the individual tumour microenvironment and associated tumour macrophage type.

Studies directly linking the immunomodulatory mechanisms of metabolic hormones on macrophages to cancer development are limited. However, macrophages pervade almost every organ system and so the potential of dysregulated hormone levels to modulate macrophage biology into pro-cancerous phenotypes may be significant. Therefore, studies are urgently needed to better understand the interplay between these metabolic hormones, immune cells such as macrophages and cancer development. Such research may help identify novel cancer treatment strategies which may focus for example on normalising levels of dysregulated metabolic hormones or targeting the hormone receptors or aberrantly activated intracellular signalling pathways. 


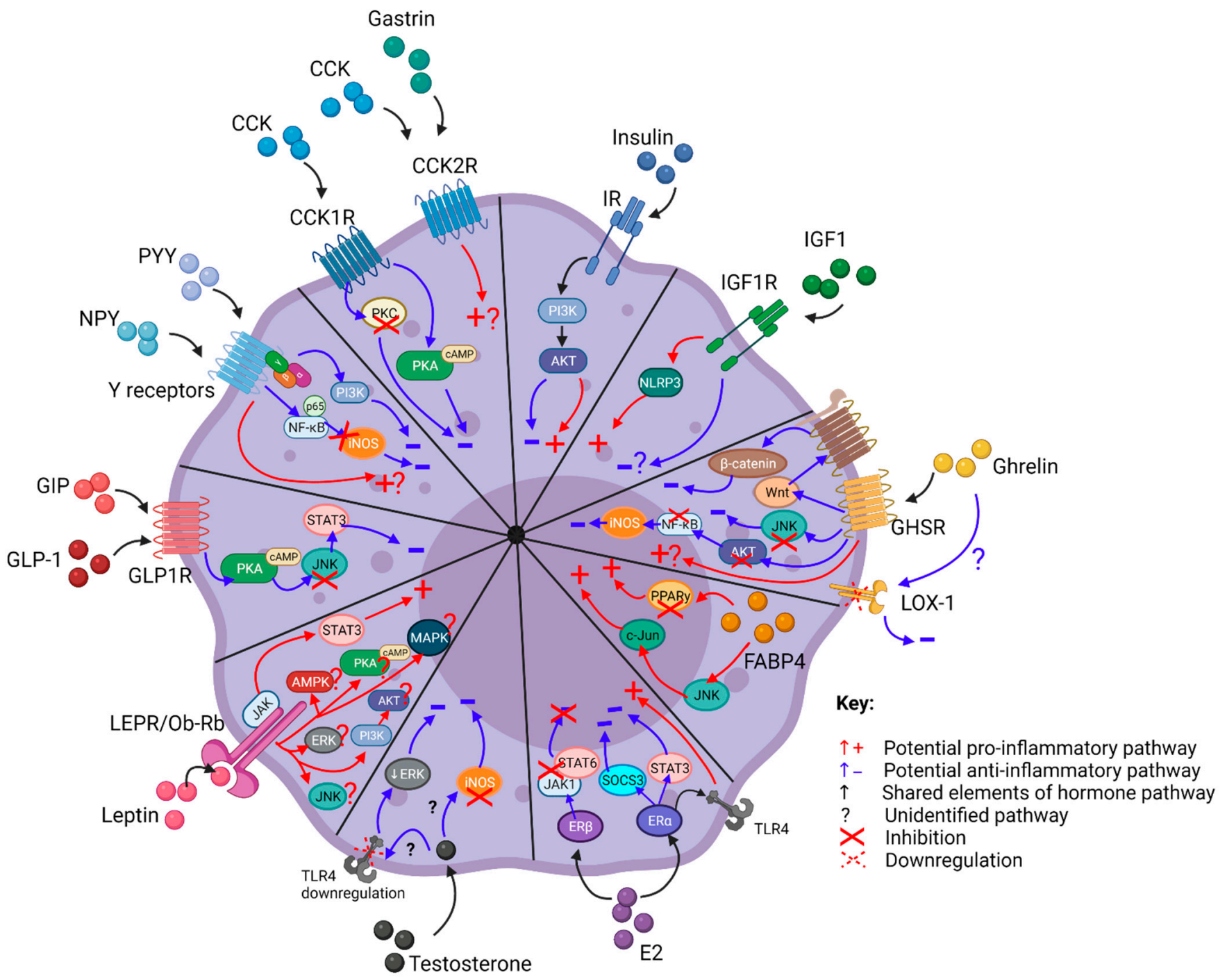

Figure 3. Schematic summarising the potential intracellular signalling mechanisms by which metabolic hormones affect macrophage inflammatory responses. This figure was created with Biorender.com.

Author Contributions: Conceptualization M.C.G.; writing—original draft preparation M.J.B., G.C., A.S. and M.C.G.; writing-review and editing M.J.B., G.C., A.S. and M.C.G.; supervision M.C.G.; project administration M.C.G. All authors have read and agreed to the published version of the manuscript.

Funding: This research was supported by British Heart Foundation (BHF) Project Grant PG/16/87/32492. (to M.C.G) and a Diabetes UK Project Grant 17/0005682 (to M.C.G).

Conflicts of Interest: The authors declare no conflict of interest.

\section{References}

1. De Pergola, G.; Silvestris, F. Obesity as a major risk factor for cancer. J. Obes. 2013, 2013, 291546. [CrossRef] [PubMed]

2. Lean, M.E.J.; Malkova, D. Altered gut and adipose tissue hormones in overweight and obese individuals: Cause or consequence? Int. J. Obes. 2016, 40, 622-632. [CrossRef]

3. Chawla, A.; Nguyen, K.D.; Goh, Y.P.S.S. Macrophage-Mediated Inflammation in Metabolic Disease. Nat. Rev. Immunol. 2011, 11, 738-749. [CrossRef]

4. Lin, Y.; Xu, J.; Lan, H. Tumor-associated macrophages in tumor metastasis: Biological roles and clinical therapeutic applications. J. Hematol. Oncol. 2019, 12, 76. [CrossRef]

5. Na, Y.R.; Je, S.; Seok, S.H. Metabolic features of macrophages in inflammatory diseases and cancer. Cancer Lett. 2018, 413, 46-58. [CrossRef] 
6. Murray, P.J.; Allen, J.E.; Biswas, S.K.; Fisher, E.A.; Gilroy, D.W.; Goerdt, S.; Gordon, S.; Hamilton, J.A.; Ivashkiv, L.B.; Lawrence, T.; et al. Macrophage Activation and Polarization: Nomenclature and Experimental Guidelines. Immunity 2014, 41, 14-20. [CrossRef]

7. Chinetti-Gbaguidi, G.; Staels, B. Macrophage polarization in metabolic disorders: Functions and regulation. Curr. Opin. Lipidol. 2011, 22, 365-372. [CrossRef]

8. Xue, J.; Schmidt, S.V.; Sander, J.; Draffehn, A.; Krebs, W.; Quester, I.; DeNardo, D.; Gohel, T.D.; Emde, M.; Schmidleithner, L.; et al. Transcriptome-Based Network Analysis Reveals a Spectrum Model of Human Macrophage Activation. Immunity 2014, 40, 274-288. [CrossRef]

9. Kazankov, K.; Jørgensen, S.M.D.; Thomsen, K.L.; Møller, H.J.; Vilstrup, H.; George, J.; Schuppan, D.; Grønbæk, H. The role of macrophages in nonalcoholic fatty liver disease and nonalcoholic steatohepatitis. Nat. Rev. Gastroenterol. Hepatol. 2019, 16, 145-159. [CrossRef]

10. Butcher, M.J.; Galkina, E.V. Phenotypic and functional heterogeneity of macrophages and dendritic cell subsets in the healthy and atherosclerosis-prone aorta. Front. Physiol. 2012, 3, 44. [CrossRef]

11. Cendrowicz, E.; Sas, Z.; Bremer, E.; Rygiel, T.P. The Role of Macrophages in Cancer Development and Therapy. Cancers 2021, 13, 1946. [CrossRef]

12. Mantovani, A.; Marchesi, F.; Malesci, A.; Laghi, L.; Allavena, P. Tumour-associated macrophages as treatment targets in oncology. Nat. Rev. Clin. Oncol. 2017, 14, 399-416. [CrossRef]

13. Jurberg, A.D.; Cotta-de-Almeida, V.; Temerozo, J.R.; Savino, W.; Bou-Habib, D.C.; Riederer, I. Neuroendocrine Control of Macrophage Development and Function. Front. Immunol. 2018, 9, 1440. [CrossRef]

14. Dufresne, M.; Seva, C.; Fourmy, D. Cholecystokinin and gastrin receptors. Physiol. Rev. 2006, 86. [CrossRef] [PubMed]

15. Desai, A.J.; Dong, M.; Harikumar, K.G.; Miller, L.J. Cholecystokinin-induced satiety, a key gut servomechanism that is affected by the membrane microenvironment of this receptor. Int. J. Obes. Suppl. 2016, 6, S22-S27. [CrossRef]

16. Rehfeld, J.F. Cholecystokinin-From local gut hormone to ubiquitous messenger. Front. Endocrinol. 2017, 8, 47. [CrossRef]

17. Wank, S.A.; Pisegna, J.R.; Weerth, A. De Brain and gastrointestinal cholecystokinin receptor family: Structure and functional expression. Proc. Natl. Acad. Sci. USA 1992, 89, 8691-8695. [CrossRef]

18. Kopin, A.S.; Lee, Y.M.; McBride, E.W.; Miller, L.J.; Lu, M.; Lin, H.Y.; Kolakowski, L.F.; Beinborn, M. Expression cloning and characterization of the canine parietal cell gastrin receptor. Proc. Natl. Acad. Sci. USA 1992, 89, 3605-3609. [CrossRef]

19. Schjoldager, B. Role of CCK in gallbladder function. Ann. N. Y. Acad. Sci. 1994, 713, 207-218. [CrossRef]

20. Nadella, S.; Burks, J.; Al-Sabban, A.; Inyang, G.; Wang, J.; Tucker, R.D.; Zamanis, M.E.; Bukowski, W.; Shivapurkar, N.; Smith, J.P. Dietary fat stimulates pancreatic cancer growth and promotes fibrosis of the tumor microenvironment through the cholecystokinin receptor. Am. J. Physiol. Gastrointest. Liver Physiol. 2018, 315, G699-G712. [CrossRef]

21. Smith, J.P.; Verderame, M.F.; McLaughlin, P.; Martenis, M.; Ballard, E.; Zagon, I.S. Characterization of the CCK-C (cancer) receptor in human pancreatic cancer. Int. J. Mol. Med. 2002, 10, 689-694. [CrossRef] [PubMed]

22. Matters, G.L.; Cooper, T.K.; Mcgovern, C.O.; Gilius, E.L.; Liao, J.; Barth, B.M.; Kester, M.; Smith, J.P.; Matters, G.L.; Cooper, T.K.; et al. Cholecystokinin Mediates Progression and Metastasis of Pancreatic Cancer Associated with Dietary Fat. Dig. Dis. Sci. 2014, 59, 1180-1191. [CrossRef]

23. Reubi, J.C. Targeting CCK receptors in human cancers. Curr. Top. Med. Chem. 2007, 7, 1239-1242. [CrossRef] [PubMed]

24. Zeng, Q.; Ou, L.; Wang, W.; Guo, D.Y. Gastrin, Cholecystokinin, Signaling, and Biological Activities in Cellular Processes. Front. Endocrinol. 2020, 11, 112. [CrossRef] [PubMed]

25. Zhang, Y.; Zhu, J.; Guo, L.; Zou, Y.; Wang, F.; Shao, H.; Li, J.; Deng, X. Cholecystokinin protects mouse liver against ischemia and reperfusion injury. Int. Immunopharmacol. 2017, 48, 180-186. [CrossRef]

26. Meng, A.H.; Ling, Y.L.; Zhang, X.P.; Zhang, J.L. Anti-inflammatory effect of cholecystokinin and its signal transduction mechanism in endotoxic shock rat. World J. Gastroenterol. 2002, 8, 712. [CrossRef]

27. Bozkurt, A.; Çakir, B.; Ercan, F.; Yeğen, B.Ç. Anti-inflammatory effects of leptin and cholecystokinin on acetic acid-induced colitis in rats: Role of capsaicin-sensitive vagal afferent fibers. Regul. Pept. 2003, 116, 109-118. [CrossRef]

28. Luyer, M.D.; Greve, J.W.M.; Hadfoune, M.; Jacobs, J.A.; Dejong, C.H.; Buurman, W.A. Nutritional stimulation of cholecystokinin receptors inhibits inflammation via the vagus nerve. J. Exp. Med. 2005, 202, 1023-1029. [CrossRef]

29. Saia, R.S.; Mestriner, F.L.; Bertozi, G.; Cunha, F.Q.; Cárnio, E.C. Cholecystokinin Inhibits Inducible Nitric Oxide Synthase Expression by Lipopolysaccharide-Stimulated Peritoneal Macrophages. Mediat. Inflamm. 2014, 2014, 896029. [CrossRef]

30. Miyamoto, S.; Shikata, K.; Miyasaka, K.; Okada, S.; Sasaki, M.; Kodera, R.; Hirota, D.; Kajitani, N.; Takatsuka, T.; Kataoka, H.U.; et al. Cholecystokinin plays a novel protective role in diabetic kidney through anti-inflammatory actions on macrophage: Anti-inflammatory effect of cholecystokinin. Diabetes 2012, 61, 897-907. [CrossRef]

31. Ling, Y.L.; Meng, A.H.; Zhao, X.Y.; Shan, B.E.; Zhang, J.L.; Zhang, X.P. Effect of cholecystokinin on cytokines during endotoxic shock in rats. World J. Gastroenterol. 2001, 7, 667. [CrossRef]

32. Ye, S.; Shi, K.; Xu, J.; Wang, M.; Li, C.J. Cholecystokinin octapeptide inhibits the inflammatory response and improves neurological outcome in a porcine model of cardiopulmonary resuscitation. Exp. Ther. Med. 2018, 15, 2583-2588. [CrossRef] [PubMed]

33. Zuelli, F.M.D.G.C.; Cárnio, E.C.; Saia, R.S. Cholecystokinin protects rats against sepsis induced by Staphylococcus aureus. Med. Microbiol. Immunol. 2014, 203, 165-176. [CrossRef] 
34. Sacerdote, P.; Wiedermann, C.J.; Wahl, L.M.; Pert, C.B.; Ruff, M.R. Visualization of cholecystokinin receptors on a subset of human monocytes and in rat spleen. Peptides 1991, 12, 167-176. [CrossRef]

35. Xu, S.J.; Gao, W.J.; Cong, B.; Yao, Y.X.; Gu, Z.Y. Effect of lipopolysaccharide on expression and characterization of cholecystokinin receptors in rat pulmonary interstitial macrophages. Acta Pharmacol. Sin. 2004, 25, 1347-1353.

36. Li, S.; Ni, Z.; Cong, B.; Gao, W.; Xu, S.; Wang, C.; Yao, Y.; Ma, C.; Ling, Y. CCK-8 inhibits LPS-induced IL-1 $\beta$ production in pulmonary interstitial macrophages by modulating PKA, p38, and NF-kB pathway. Shock 2007, 27, 678-686. [CrossRef]

37. De la Fuente, M.; Campos, M.; Del Rio, M.; Hernanz, A. Inhibition of murine peritoneal macrophage functions by sulfated cholecystokinin octapeptide. Regul. Pept. 1995, 55, 47-56. [CrossRef]

38. Cong, B.; Li, S.J.; Yao, Y.X.; Zhu, G.J.; Ling, Y.L. Effect of cholecystokinin octapeptide on tumor necrosis factor $\alpha$ transcription and nuclear factor- $\mathrm{kB}$ activity induced by lipopolysaccharide in rat pulmonary interstitial macrophages. World J. Gastroenterol. 2002, 8, 718. [CrossRef] [PubMed]

39. Furuhashi, M.; Hotamisligil, G.S. Fatty acid-binding proteins: Role in metabolic diseases and potential as drug targets. Nat. Rev. Drug Discov. 2008, 7, 489-503. [CrossRef]

40. Saye, J.A.; Lynch, K.R.; Peach, M.J. Changes in angiotensinogen messenger RNA in differentiating 3T3-F442A adipocytes. Hypertension 1990, 15, 867-871. [CrossRef]

41. Hunt, C.R.; Ro, J.H.S.; Dobson, D.E.; Min, H.Y.; Spiegelman, B.M. Adipocyte P2 gene: Developmental expression and homology of 5'-flanking sequences among fat cell-specific genes. Proc. Natl. Acad. Sci. USA 1986, 83, 3786-3790. [CrossRef]

42. Makowski, L.; Boord, J.B.; Maeda, K.; Babaev, V.R.; Uysal, K.T.; Morgan, M.A.; Parker, R.A.; Suttles, J.; Fazio, S.; Hotamisligil, G.S.; et al. Lack of macrophage fatty-acid-binding protein aP2 protects mice deficient in apolipoprotein $\mathrm{E}$ against atherosclerosis. Nat. Med. 2001, 7, 699-705. [CrossRef]

43. Pelton, P.D.; Zhou, L.; Demarest, K.T.; Burris, T.P. PPAR $\gamma$ activation induces the expression of the adipocyte fatty acid binding protein gene in human monocytes. Biochem. Biophys. Res. Commun. 1999, 261, 456-458. [CrossRef]

44. Tontonoz, P.; Graves, R.A.; Budavari, A.I.; Erdjument-bromage, H.; Lui, M.; Hu, E.; Tempst, P.; Spiegelman, B.M. Adipocytespecific transcription factor ARF6 is a heterodimeric complex of two nuclear hormone receptors, PPAR $\gamma$ and RXRa. Nucleic Acids Res. 1994, 22, 5628-5634. [CrossRef] [PubMed]

45. Xu, A.; Tso, A.W.K.; Cheung, B.M.Y.; Wang, Y.; Wat, N.M.S.; Fong, C.H.Y.; Yeung, D.C.Y.; Janus, E.D.; Sham, P.C.; Lam, K.S.L. Circulating adipocyte-fatty acid binding protein levels predict the development of the metabolic syndrome: A 5-year prospective study. Circulation 2007, 115, 1537-1543. [CrossRef]

46. Tso, A.W.K.; Xu, A.; Sham, P.C.; Wat, N.M.S.; Wang, Y.; Fong, C.H.Y.; Cheung, B.M.Y.; Janus, E.D.; Lam, K.S.L. Serum adipocyte fatty acid-binding protein as a new biomarker predicting the development of type 2 diabetes: A 10-year prospective study in a Chinese cohort. Diabetes Care 2007, 30, 2667-2672. [CrossRef] [PubMed]

47. Tuncman, G.; Erbay, E.; Hom, X.; De Vivo, I.; Campos, H.; Rimm, E.B.; Hotamisligil, G.S. A genetic variant at the fatty acid-binding protein aP2 locus reduces the risk for hypertriglyceridemia, type 2 diabetes, and cardiovascular disease. Proc. Natl. Acad. Sci. USA 2006, 103, 6970-6975. [CrossRef]

48. Yeung, D.C.Y.; Xu, A.; Cheung, C.W.S.; Wat, N.M.S.; Yau, M.H.; Fong, C.H.Y.; Chau, M.T.; Lam, K.S.L. Serum adipocyte fatty acid-binding protein levels were independently associated with carotid atherosclerosis. Arterioscler. Thromb. Vasc. Biol. 2007, 27, 1796-1802. [CrossRef]

49. Hao, J.; Yan, F.; Zhang, Y.Y.; Triplett, A.; Zhang, Y.Y.; Schultz, D.A.; Sun, Y.; Zeng, J.; Silverstein, K.A.T.; Zheng, Q.; et al. Expression of adipocyte/macrophage fatty acid-binding protein in tumor-associated macrophages promotes breast cancer progression. Cancer Res. 2018, 78, 2343-2355. [CrossRef] [PubMed]

50. Zhong, C.-Q.; Zhang, X.-P.; Ma, N.; Zhang, E.-B.; Li, J.-J.; Jiang, Y.-B.; Gao, Y.-Z.; Yuan, Y.-M.; Lan, S.-Q.; Xie, D.; et al. FABP4 suppresses proliferation and invasion of hepatocellular carcinoma cells and predicts a poor prognosis for hepatocellular carcinoma. Cancer Med. 2018, 7, 2629-2640. [CrossRef] [PubMed]

51. Tian, W.; Zhang, W.; Zhang, Y.; Zhu, T.; Hua, Y.; Li, H.; Zhang, Q.; Xia, M. FABP4 promotes invasion and metastasis of colon cancer by regulating fatty acid transport. Cancer Cell Int. 2020, 20, 512. [CrossRef]

52. Gharpure, K.M.; Pradeep, S.; Sans, M.; Rupaimoole, R.; Ivan, C.; Wu, S.Y.; Bayraktar, E.; Nagaraja, A.S.; Mangala, L.S.; Zhang, X.; et al. FABP4 as a key determinant of metastatic potential of ovarian cancer. Nat. Commun. 2018, 9, 2923. [CrossRef]

53. Harjes, U.; Bridges, E.; Gharpure, K.M.; Roxanis, I.; Sheldon, H.; Miranda, F.; Mangala, L.S.; Pradeep, S.; Lopez-Berestein, G.; Ahmed, A.; et al. Antiangiogenic and tumour inhibitory effects of downregulating tumour endothelial FABP4. Oncogene 2017, 36, 912-921. [CrossRef]

54. Nieman, K.M.; Kenny, H.A.; Penicka, C.V.; Ladanyi, A.; Buell-Gutbrod, R.; Zillhardt, M.R.; Romero, I.L.; Carey, M.S.; Mills, G.B.; Hotamisligil, G.S.; et al. Adipocytes promote ovarian cancer metastasis and provide energy for rapid tumor growth. Nat. Med. 2011, 17, 1498-1503. [CrossRef] [PubMed]

55. Hardaway, A.L.; Podgorski, I. IL-1 $\beta$, RAGE and FABP4: Targeting the dynamic trio in metabolic inflammation and related pathologies. Futur. Med. Chem. 2013, 5. [CrossRef] [PubMed]

56. Garin-Shkolnik, T.; Rudich, A.; Hotamisligil, G.S.; Rubinstein, M. FABP4 attenuates PPAR $\gamma$ and adipogenesis and is inversely correlated with PPAR $\gamma$ in adipose tissues. Diabetes 2014, 63, 900-911. [CrossRef]

57. Rigamonti, E.; Chinetti-Gbaguidi, G.; Staels, B. Regulation of macrophage functions by PPAR- $\alpha$, PPAR- $\gamma$, and LXRs in mice and men. Arterioscler. Thromb. Vasc. Biol. 2008, 28, 1050-1059. [CrossRef] 
58. Ricote, M.; Glass, C.K. PPARs and molecular mechanisms of transrepression. Biochim. Biophys. Acta-Mol. Cell Biol. Lipids 2007, 1771, 926-935. [CrossRef]

59. Ricote, M.; Li, A.C.; Willson, T.M.; Kelly, C.J.; Glass, C.K. The peroxisome proliferator-activated receptor- $\gamma$ is a negative regulator of macrophage activation. Nature 1998, 391, 79-82. [CrossRef]

60. Odegaard, J.I.; Ricardo-Gonzalez, R.R.; Goforth, M.H.; Morel, C.R.; Subramanian, V.; Mukundan, L.; Eagle, A.R.; Vats, D.; Brombacher, F.; Ferrante, A.W.; et al. Macrophage-specific PPAR $\gamma$ controls alternative activation and improves insulin resistance. Nature 2007, 447, 1116-1120. [CrossRef] [PubMed]

61. Makowski, L.; Brittingham, K.C.; Reynolds, J.M.; Suttles, J.; Hotamisligil, G.S. The fatty acid-binding protein, aP2, coordinates macrophage cholesterol trafficking and inflammatory activity: Macrophage expression of aP2 impacts peroxisome proliferatoractivated receptor $\gamma$ and IKB kinase activities. J. Biol. Chem. 2005, 280, 12888-12895. [CrossRef]

62. Layne, M.D.; Patel, A.; Chen, Y.-H.; Rebel, V.I.; Carvajal, I.M.; Pellacani, A.; Ith, B.; Zhao, D.; Schreiber, B.M.; Yet, S.-F.; et al. Role of macrophage-expressed adipocyte fatty acid binding protein in the development of accelerated atherosclerosis in hypercholesterolemic mice. FASEB J. 2001, 15, 1-19. [CrossRef]

63. Hui, X.; Li, H.; Zhou, Z.; Lam, K.S.L.; Xiao, Y.; Wu, D.; Ding, K.; Wang, Y.; Vanhoutte, P.M.; Xu, A. Adipocyte fatty acid-binding protein modulates inflammatory responses in macrophages through a positive feedback loop involving c-Jun NH 2-terminal kinases and activator protein-1. J. Biol. Chem. 2010, 285, 10273-10280. [CrossRef]

64. Boß, M.; Kemmerer, M.; Brüne, B.; Namgaladze, D. FABP4 inhibition suppresses PPAR $\gamma$ activity and VLDL-induced foam cell formation in IL-4-polarized human macrophages. Atherosclerosis 2015, 240, 424-430. [CrossRef]

65. Liu, Q.Y.; Nambi, P. Sirolimus upregulates aP2 expression in human monocytes and macrophages. Transplant. Proc. 2004, 36, 3229-3231. [CrossRef]

66. Calatayud, S.; Alvarez, A.; Victor, V.M. Gastrin: An Acid-Releasing, Proliferative and Immunomodulatory Peptide? Mini-Rev. Med. Chem. 2010, 10, 8-19. [CrossRef]

67. Hiraoka, S.; Miyazaki, Y.; Kitamura, S.; Toyota, M.; Kiyohara, T.; Shinomura, Y.; Mukaida, N.; Matsuzawa, Y. Gastrin induces CXC chemokine expression in gastric epithelial cells through activation of NF-кB. Am. J. Physiol. Liver Physiol. 2001, 281, G735-G742. [CrossRef] [PubMed]

68. Subramaniam, D.; Ramalingam, S.; May, R.; Dieckgraefe, B.K.; Berg, D.E.; Pothoulakis, C.; Houchen, C.W.; Wang, T.C.; Anant, S. Gastrin-Mediated Interleukin-8 and Cyclooxygenase-2 Gene Expression: Differential Transcriptional and Posttranscriptional Mechanisms. Gastroenterology 2008, 134, 1070-1082. [CrossRef]

69. Grösch, S.; Maier, T.J.; Schiffmann, S.; Geisslinger, G. Cyclooxygenase-2 (COX-2)-Independent Anticarcinogenic Effects of Selective COX-2 Inhibitors. JNCI J. Natl. Cancer Inst. 2006, 98, 736-747. [CrossRef]

70. Chao, C.; Hellmich, M.R. Gastrin, inflammation, and carcinogenesis. Curr. Opin. Endocrinol. Diabetes Obes. 2010, 17, 33-39. [CrossRef] [PubMed]

71. Bedke, J.; Hemmerlein, B.; Perske, C.; Gross, A.; Heuser, M. Tumor-associated macrophages in clear cell renal cell carcinoma express both gastrin-releasing peptide and its receptor: A possible modulatory role of immune effectors cells. World J. Urol. 2010, 28, 335-341. [CrossRef]

72. Levine, L.; Lucci, J.A.; Pazdrak, B.; Cheng, J.Z.; Guo, Y.S.; Townsend, C.M.; Hellmich, M.R. Bombesin stimulates nuclear factor kB activation and expression of proangiogenic factors in prostate cancer cells. Cancer Res. 2003, 63, 3495-3502. [PubMed]

73. Mezey, É.; Palkovits, M. Localization of targets for anti-ulcer drugs in cells of the immune system. Science 1992, 258, 1662-1665. [CrossRef]

74. Schmitz, F.; Schrader, H.; Otte, J.M.; Schmitz, H.; Stüber, E.; Herzig, K.H.; Schmidt, W.E. Identification of CCK-B/gastrin receptor splice variants in human peripheral blood mononuclear cells. Regul. Pept. 2001, 101, 25-33. [CrossRef]

75. Iwata, N.; Murayama, T.; Matsumori, Y.; Ito, M.; Nagata, A.; Taniguchi, T.; Chihara, K.; Matsuo, Y.; Minowada, J.; Matsui, T. Autocrine loop through cholecystokinin-B/gastrin receptors involved in growth of human leukemia cells. Blood 1996, 88, 2683-2689. [CrossRef] [PubMed]

76. Schmitz, F.; Otte, J.M.; Stechele, H.U.; Reimann, B.; Banasiewicz, T.; Fölsch, U.R.; Schmidt, W.E.; Herzig, K.H. CCK-B/gastrin receptors in human colorectal cancer. Eur. J. Clin. Investig. 2001, 31, 812-820. [CrossRef]

77. Okahata, H.; Nishi, Y.; Muraki, K.; Sumii, K.; Miyachi, Y.; Usui, T. Gastrin/cholecystokinin-like immunoreactivity in human blood cells. Life Sci. 1985, 36, 369-373. [CrossRef]

78. De La Fuente, M.; Drummond, J.; Del Rio, M.; Carrasco, M.; Hernanz, A. Modulation of murine peritoneal macrophage functions by gastrin. Peptides 1996, 17, 219-224. [CrossRef]

79. De La Fuente, M.; Carrasco, M.; Hernanz, A. Modulation of human neutrophil function in vitro by gastrin. J. Endocrinol. 1997, 153, 475-483. [CrossRef]

80. Álvarez, Á.; Ibiza, S.; Hernández, C.; Álvarez-Barrientos, A.; Esplugues, J.V.; Calatayud, S.; Álvarez, Á.; Ibiza, S.; Hernández, C.; Álvarez-Barrientos, A.; et al. Gastrin induces leukocyte-endothelial cell interactions in vivo and contributes to the inflammation caused by Helicobacter pylori. FASEB J. 2006, 20, 2396-2398. [CrossRef]

81. Kim, S.O.; Chao, C.; Townsend, C.M.; Hellmich, M.R. M1632 Interferon- $\gamma$ Induces CCK2 Receptor Expression in Monocytes and Bone Marrow-Derived Cells. Gastroenterology 2009, 136, A-398. [CrossRef] 
82. Lefranc, F.; Mijatovic, T.; Mathieu, V.; Rorive, S.; Decaestecker, C.; Debeir, O.; Brotchi, J.; Van Ham, P.; Salmon, I.; Kiss, R. Characterization of gastrin-induced proangiogenic effects in vivo in orthotopic U373 experimental human glioblastomas and in vitro in human umbilical vein endothelial cells. Clin. Cancer Res. 2004, 10, 8250-8265. [CrossRef]

83. Ibiza, S.; Álvarez, Á.; Romero, W.; Barrachina, M.D.; Esplugues, J.V.; Calatayud, S. Gastrin induces the interaction between human mononuclear leukocytes and endothelial cells through the endothelial expression of P-selectin and VCAM-1. Am. J. Physiol.-Cell Physiol. 2009, 297, C1588-C1595. [CrossRef] [PubMed]

84. Kojima, M.; Hosoda, H.; Date, Y.; Nakazato, M.; Matsuo, H.; Kangawa, K. Ghrelin is a growth-hormone-releasing acylated peptide from stomach. Nature 1999, 402, 656-660. [CrossRef] [PubMed]

85. Ferrini, F.; Salio, C.; Lossi, L.; Merighi, A. Ghrelin in central neurons. Curr. Neuropharmacol. 2009, 7, 37-49. [CrossRef] [PubMed]

86. Waseem, T.; Duxbury, M.; Ito, H.; Ashley, S.W.; Robinson, M.K. Exogenous ghrelin modulates release of pro-inflammatory and anti-inflammatory cytokines in LPS-stimulated macrophages through distinct signaling pathways. Surgery 2008, 143, 334-342. [CrossRef]

87. Tschop, M.; Smiley, D.L.; Heiman, M.L. Ghrelin induces adiposity in rodents. Nature 2000, 407, 908-913. [CrossRef]

88. Kojima, M.; Kangawa, K. Ghrelin: Structure and function. Physiol. Rev. 2005, 85, 495-522. [CrossRef]

89. Garin, M.C.; Burns, C.M.; Kaul, S.; Cappola, A.R. The human experience with ghrelin administration. J. Clin. Endocrinol. Metab. 2013, 98, 1826-1837. [CrossRef] [PubMed]

90. Dixit, V.D.; Palaniappan, R.; Collins, G.D.; Taub, D.D.; Sakthivel, S.K.; Lillard, J.W.; Schaffer, E.M.; Pyle, R.S.; Collins, G.D.; Sakthivel, S.K.; et al. Ghrelin inhibits leptin- and activation-induced proinflammatory cytokine expression by human monocytes and T cells. J. Clin. Investig. 2004, 114, 57-66. [CrossRef]

91. Hattori, N.; Saito, T.; Yagyu, T.; Jiang, B.H.; Kitagawa, K.; Inagaki, C. GH, GH receptor, GH secretagogue receptor, and Ghrelin expression in human T cells, B cells, and neutrophils. J. Clin. Endocrinol. Metab. 2001, 86, 4284-4291. [CrossRef]

92. Li, B.; Zeng, M.; He, W.; Huang, X.; Luo, L.; Zhang, H.; Deng, D.Y.B. Ghrelin protects alveolar macrophages against lipopolysaccharide-induced apoptosis through growth hormone secretagogue receptor 1a-dependent c-jun n-terminal kinase and wnt/ B-catenin signaling and suppresses lung inflammation. Endocrinology 2015, 156, 203-217. [CrossRef]

93. Shiiya, T.; Nakazato, M.; Mizuta, M.; Date, Y.; Mondal, M.S.; Tanaka, M.; Nozoe, S.I.; Hosoda, H.; Kangawa, K.; Matsukura, S. Plasma ghrelin levels in lean and obese humans and the effect of glucose on ghrelin secretion. J. Clin. Endocrinol. Metab. 2002, 87, 240-244. [CrossRef]

94. Naznin, F.; Toshinai, K.; Waise, T.M.Z.; Okada, T.; Sakoda, H.; Nakazato, M. Restoration of metabolic inflammation-related ghrelin resistance by weight loss. J. Mol. Endocrinol. 2018, 60, 109-118. [CrossRef]

95. Soleyman-Jahi, S.; Sadeghi, F.; Pastaki Khoshbin, A.; Khani, L.; Roosta, V.; Zendehdel, K. Attribution of Ghrelin to Cancer; Attempts to Unravel an Apparent Controversy. Front. Oncol. 2019, 9, 1014. [CrossRef]

96. Tian, C.; Zhang, L.; Hu, D.; Ji, J. Ghrelin induces gastric cancer cell proliferation, migration, and invasion through GHS-R/NF- $\mathrm{kB}$ signaling pathway. Mol. Cell. Biochem. 2013, 382, 163-172. [CrossRef]

97. Murphy, G.; Kamangar, F.; Dawsey, S.M.; Stanczyk, F.Z.; Weinstein, S.J.; Taylor, P.R.; Virtamo, J.; Abnet, C.C.; Albanes, D.; Freedman, N.D. The Relationship Between Serum Ghrelin and the Risk of Gastric and Esophagogastric Junctional Adenocarcinomas. JNCI J. Natl. Cancer Inst. 2011, 103, 1123-1129. [CrossRef]

98. Spiridon, I.A.; Ciobanu, D.G.A.; Giușcă, S.E.; Căruntu, I.D. Ghrelin and its role in gastrointestinal tract tumors (Review). Mol. Med. Rep. 2021, 24, 663. [CrossRef]

99. Sever, S.; White, D.L.; Garcia, J.M. Is there an effect of ghrelin/ghrelin analogs on cancer? A systematic review. Endocr. Relat. Cancer 2016, 23, R393-R409. [CrossRef]

100. Yuan, F.; Ma, J.; Xiang, X.; Lan, H.; Xu, Y.; Zhao, J.; Li, Y.; Zhang, W. Improvement of Adipose Macrophage Polarization in High Fat Diet-Induced Obese GHSR Knockout Mice. Biomed Res. Int. 2018, 2018, 4924325. [CrossRef]

101. Lin, L.; Lee, J.H.; Buras, E.D.; Yu, K.; Wang, R.; Smith, C.W.; Wu, H.; Sheikh-Hamad, D.; Sun, Y. Ghrelin receptor regulates adipose tissue inflammation in aging. Aging 2016, 8, 178. [CrossRef]

102. Ai, W.; Wu, M.; Chen, L.; Jiang, B.; Mu, M.; Liu, L.; Yuan, Z. Ghrelin ameliorates atherosclerosis by inhibiting endoplasmic reticulum stress. Fundam. Clin. Pharmacol. 2017, 31, 147-154. [CrossRef]

103. Raghay, K.; Akki, R.; Bensaid, D.; Errami, M. Ghrelin as an anti-inflammatory and protective agent in ischemia/reperfusion injury. Peptides 2020, 124, 170226. [CrossRef]

104. Pang, J.; Xu, Q.; Xu, X.; Yin, H.; Xu, R.; Guo, S.; Hao, W.; Wang, L.; Chen, C.; Cao, J.M. Hexarelin suppresses high lipid diet and vitamin D3-induced atherosclerosis in the rat. Peptides 2010, 31, 630-638. [CrossRef]

105. Li, W.G.; Gavrila, D.; Liu, X.; Wang, L.; Gunnlaugsson, S.; Stoll, L.L.; McCormick, M.L.; Sigmund, C.D.; Tang, C.; Weintraub, N.L. Ghrelin Inhibits Proinflammatory Responses and Nuclear Factor-кB Activation in Human Endothelial Cells. Circulation 2004, 109, 2221-2226. [CrossRef]

106. Wang, L.; Chen, Q.; Ke, D.; Li, G. Ghrelin inhibits atherosclerotic plaque angiogenesis and promotes plaque stability in a rabbit atherosclerotic model. Peptides 2017, 90, 17-26. [CrossRef]

107. Sun, J.; Li, X.; Jiao, K.; Zhai, Z.; Sun, D. Albiflorin inhibits the formation of THP-1-derived foam cells through the LOX-1/NF-kB pathway. Minerva Med. 2019, 110, 107-114. [CrossRef]

108. Cheng, X.L.; Ding, F.; Wang, D.P.; Zhou, L.; Cao, J.M. Hexarelin attenuates atherosclerosis via inhibiting LOX-1-NF-кB signaling pathway-mediated macrophage ox-LDL uptake in ApoE-/- mice. Peptides 2019, 121, 170122. [CrossRef] 
109. Sun, N.; Wang, H.; Wang, L. Ghrelin inhibits oxLDL-induced inflammation in RAW264.7 mouse macrophages through downregulation of LOX-1 expression via NF-кB signaling pathway. Cell. Mol. Biol. 2016, 62, 57-61. [CrossRef] [PubMed]

110. Zheng, H.; Liang, W.; He, W.; Huang, C.; Chen, Q.; Yi, H.; Long, L.; Deng, Y.; Zeng, M. Ghrelin attenuates sepsis-induced acute lung injury by inhibiting the NF-kB, iNOS, and Akt signaling in alveolar macrophages. Am. J. Physiol.-Lung Cell. Mol. Physiol. 2019, 317, L381-L391. [CrossRef]

111. Nogi, Y.; Nagashima, M.; Terasaki, M.; Nohtomi, K.; Watanabe, T.; Hirano, T. Glucose-dependent insulinotropic polypeptide prevents the progression of macrophage-driven atherosclerosis in diabetic apolipoprotein E-null mice. PLoS ONE 2012, 7, e35683. [CrossRef]

112. Seino, S.; Shibasaki, T.; Minami, K. Dynamics of insulin secretion and the clinical implications for obesity and diabetes. J. Clin. Investig. 2011, 121, 2118-2125. [CrossRef]

113. Eissele, R.; Göke, R.; Willemer, S.; Harthus, H.-P.; Vermeer, H.; Arnold, R.; Göke, B. Glucagon-like peptide-1 cells in the gastrointestinal tract and pancreas of rat, pig and man. Eur. J. Clin. Investig. 1992, 22, 283-291. [CrossRef]

114. Bell, G.I.; Santerre, R.F.; Mullenbach, G.T. Hamster preproglucagon contains the sequence of glucagon and two related peptides. Nature 1983, 302, 716-718. [CrossRef] [PubMed]

115. Shimizu, I.; Hirota, M.; Ohboshi, C.; Shima, K. Identification and localization of glucagon-like peptide-1 and its receptor in rat brain. Endocrinology 1987, 121, 1076-1082. [CrossRef]

116. Körner, M.; Stöckli, M.; Waser, B.; Reubi, J.C. GLP-1 receptor expression in human tumors and human normal tissues: Potential for in vivo targeting. J. Nucl. Med. 2007, 48, 736-743. [CrossRef] [PubMed]

117. Hansen, K.B.; Vilsbøll, T.; Knop, F.K. Incretin mimetics: A novel therapeutic option for patients with type 2 diabetes-A review. Diabetes. Metab. Syndr. Obes. 2010, 3, 155-163.

118. Kosowska, A.; Gallego-Colon, E.; Garczorz, W.; Kłych-Ratuszny, A.; Aghdam, M.R.F.; Woz Niak, M.; Witek, A.; WróblewskaCzech, A.; Cygal, A.; Wojnar, J.; et al. Exenatide modulates tumor-endothelial cell interactions in human ovarian cancer cells. Endocr. Connect. 2017, 6, 856-865. [CrossRef] [PubMed]

119. Fidan-Yaylal1, G.; Dodurga, Y.; Seçme, M.; Elmas, L. Antidiabetic exendin-4 activates apoptotic pathway and inhibits growth of breast cancer cells. Tumour Biol. 2016, 37, 2647-2653. [CrossRef]

120. Koehler, J.A.; Kain, T.; Drucker, D.J. Glucagon-like peptide-1 receptor activation inhibits growth and augments apoptosis in murine CT26 colon cancer cells. Endocrinology 2011, 152, 3362-3372. [CrossRef]

121. He, W.; Yu, S.; Wang, L.; He, M.; Cao, X.; Li, Y.; Xiao, H. Exendin-4 inhibits growth and augments apoptosis of ovarian cancer cells. Mol. Cell. Endocrinol. 2016, 436, 240-249. [CrossRef]

122. Rouette, J.; Yin, H.; Yu, O.H.Y.; Bouganim, N.; Platt, R.W.; Azoulay, L. Incretin-based drugs and risk of lung cancer among individuals with type 2 diabetes. Diabet. Med. 2020, 37, 868-875. [CrossRef]

123. Chai, S.; Yu, S.; Yang, Z.; Wu, S.; Gao, L.; Wang, H.; Zhang, Y.; Zhan, S.; Ji, L.; Sun, F. Effect of incretin-based therapies on cancers of digestive system among 101595 patients with type 2 diabetes mellitus: A systematic review and network meta-analysis combining 84 trials with a median duration of 30 weeks. BMJ Open Diabetes Res. Care 2019, 7, e000728. [CrossRef] [PubMed]

124. Pinto, L.C.; Falcetta, M.R.; Rados, D.V.; Leitão, C.B.; Gross, J.L. Glucagon-like peptide-1 receptor agonists and pancreatic cancer: A meta-analysis with trial sequential analysis. Sci. Rep. 2019, 9, 2375. [CrossRef]

125. Hatwal, A. Inflammation and incretins. Indian J. Endocrinol. Metab. 2012, 16, S239-S241. [CrossRef]

126. Guo, C.; Huang, T.; Chen, A.; Chen, X.; Wang, L.; Shen, F.; Gu, X. Glucagon-like peptide 1 improves insulin resistance in vitro through anti-inflammation of macrophages. Braz. J. Med. Biol. Res. 2016, 49. [CrossRef]

127. Lee, Y.S.; Shin, S.; Shigihara, T.; Hahm, E.; Liu, M.J.; Han, J.; Yoon, J.W.; Jun, H.S. Glucagon-like peptide-1 gene therapy in obese diabetic mice results in long-term cure of diabetes by improving insulin sensitivity and reducing hepatic gluconeogenesis. Diabetes 2007, 56, 1671-1679. [CrossRef]

128. Lee, Y.S.; Park, M.S.; Choung, J.S.; Kim, S.S.; Oh, H.H.; Choi, C.S.; Ha, S.Y.; Kang, Y.; Kim, Y.; Jun, H.S. Glucagon-like peptide-1 inhibits adipose tissue macrophage infiltration and inflammation in an obese mouse model of diabetes. Diabetologia 2012, 55, 2456-2468. [CrossRef]

129. Lu, C.; Xie, T.; Guo, X.; Wu, D.; Li, S.; Li, X.; Lu, Y.; Wang, X. Glucagon-like peptide-1 receptor agonist exendin-4 mitigates lipopolysaccharide-induced inflammatory responses in RAW264.7 macrophages. Int. Immunopharmacol. 2019, $77,105969$. [CrossRef]

130. Bułdak, Ł.; Machnik, G.; Bułdak, R.J.; Łabuzek, K.; Bołdys, A.; Belowski, D.; Basiak, M.; Okopień, B. Exenatide (a GLP-1 agonist) expresses anti-inflammatory properties in cultured human monocytes/macrophages in a protein kinase A and B/Akt manner. Pharmacol. Rep. 2016, 68, 329-337. [CrossRef]

131. Bułdak, Ł.; Łabuzek, K.; Bułdak, R.J.; Machnik, G.; Bołdys, A.; Okopień, B. Exenatide (a GLP-1 agonist) improves the antioxidative potential of in vitro cultured human monocytes/macrophages. Naunyn-Schmiedeberg's Arch. Pharmacol. 2015, 388, 905-919. [CrossRef] [PubMed]

132. Wan, S.; Sun, H. Glucagon-like peptide-1 modulates RAW264.7 macrophage polarization by interfering with the JNK/STAT3 signaling pathway. Exp. Ther. Med. 2019, 17, 3573-3579. [CrossRef]

133. Shiraishi, D.; Fujiwara, Y.; Komohara, Y.; Mizuta, H.; Takeya, M. Glucagon-like peptide-1 (GLP-1) induces M2 polarization of human macrophages via STAT3 activation. Biochem. Biophys. Res. Commun. 2012, 425, 304-308. [CrossRef] [PubMed] 
134. Kahles, F.; Liberman, A.; Halim, C.; Rau, M.; Möllmann, J.; Mertens, R.W.; Rückbeil, M.; Diepolder, I.; Walla, B.; Diebold, S.; et al. The incretin hormone GIP is upregulated in patients with atherosclerosis and stabilizes plaques in ApoE-/ - mice by blocking monocyte/macrophage activation. Mol. Metab. 2018, 14, 150-157. [CrossRef]

135. Vittone, F.; Liberman, A.; Vasic, D.; Ostertag, R.; Esser, M.; Walcher, D.; Ludwig, A.; Marx, N.; Burgmaier, M. Sitagliptin reduces plaque macrophage content and stabilises arteriosclerotic lesions in Apoe-/- mice. Diabetologia 2012, 55, 2267-2275. [CrossRef]

136. Ikeda, T.; Kumagai, E.; Iwata, S.; Yamakawa, A. Soluble CD26/Dipeptidyl Peptidase IV Enhances the Transcription of IL-6 and TNF-a in THP-1 Cells and Monocytes. PLoS ONE 2013, 8, e66520. [CrossRef]

137. Mooradian, A.D. Dyslipidemia in type 2 diabetes mellitus. Nat. Rev. Endocrinol. 2009, 5, 150-159. [CrossRef]

138. Lu, C.-C.; Chu, P.-Y.; Hsia, S.-M.; Wu, C.-H.; Tung, Y.-T.; Yen, G.-C. Insulin induction instigates cell proliferation and metastasis in human colorectal cancer cells. Int. J. Oncol. 2017, 50, 736-744. [CrossRef]

139. Ullrich, A.; Bell, J.R.; Chen, E.Y.; Herrera, R.; Petruzzelli, L.M.; Dull, T.J.; Gray, A.; Coussens, L.; Liao, Y.C.; Tsubokawa, M.; et al. Human insulin receptor and its relationship to the tyrosine kinase family of oncogenes. Nature 1985, 313, 756-761. [CrossRef]

140. Ebina, Y.; Ellis, L.; Jarnagin, K.; Edery, M.; Graf, L.; Clauser, E.; Ou, J.-H.; Masiarz, F.; Kan, Y.W.; Goldfine, I.D.; et al. The human insulin receptor cDNA: The structural basis for hormone-activated transmembrane signalling. Cell 1985, 40, 747-758. [CrossRef] [PubMed]

141. Ullrich, A.; Gray, A.; Tam, A.W.; Yang-Feng, T.; Tsubokawa, M.; Collins, C.; Henzel, W.; Le Bon, T.; Kathuria, S.; Chen, E. Insulin-like growth factor I receptor primary structure: Comparison with insulin receptor suggests structural determinants that define functional specificity. EMBO J. 1986, 5, 2503-2512. [CrossRef]

142. Navé, B.T.; Haigh, R.J.; Hayward, A.C.; Siddle, K.; Shepherd, P.R. Compartment-specific regulation of phosphoinositide 3-kinase by platelet-derived growth factor and insulin in 3T3-L1 adipocytes. Biochem. J. 1996, 318, 55-60. [CrossRef]

143. Haystead, C.M.M.; Gregory, P.; Shirazi, A.; Fadden, P.; Mosse, C.; Dent, P.; Haystead, T.A.J. Insulin activates a novel adipocyte mitogen-activated protein kinase kinase kinase that shows rapid phasic kinetics and is distinct from c-Raf. J. Biol. Chem. 1994, 269, 12804-12808. [CrossRef]

144. Hancock, M.L.; Meyer, R.C.; Mistry, M.; Khetani, R.S.; Wagschal, A.; Shin, T.; Ho Sui, S.J.; Näär, A.M.; Flanagan, J.G. Insulin Receptor Associates with Promoters Genome-wide and Regulates Gene Expression. Cell 2019, 177, 722-736.e22. [CrossRef] [PubMed]

145. Stewart, S.T.; Cutler, D.M.; Rosen, A.B. Forecasting the effects of obesity and smoking on U.S. life expectancy. N. Engl. J. Med. 2009, 361, 2252-2260. [CrossRef] [PubMed]

146. Calle, E.E.; Rodriguez, C.; Walker-Thurmond, K.; Thun, M.J. Overweight, obesity, and mortality from cancer in a prospectively studied cohort of U.S. adults. N. Engl. J. Med. 2003, 348, 1625-1638. [CrossRef]

147. Goodwin, P.J.; Ennis, M.; Pritchard, K.I.; Trudeau, M.E.; Koo, J.; Madarnas, Y.; Hoffman, B.; Hood, N. Fasting insulin and outcome in early-stage breast cancer: Results of a prospective cohort study. J. Clin. Oncol. 2002, 20, 42-51. [CrossRef]

148. Renehan, A.G.; Tyson, M.; Egger, M.; Heller, R.F.; Zwahlen, M. Body-mass index and incidence of cancer: A systematic review and meta-analysis of prospective observational studies. Lancet 2008, 371, 569-578. [CrossRef]

149. Pelicci, G.; Lanfrancone, L.; Grignani, F.; McGlade, J.; Cavallo, F.; Forni, G.; Nicoletti, I.; Grignani, F.; Pawson, T.; Pelicci, P.G. A novel transforming protein (SHC) with an SH2 domain is implicated in mitogenic signal transduction. Cell 1992, 70, 93-104. [CrossRef]

150. Cox, M.E.; Gleave, M.E.; Zakikhani, M.; Bell, R.H.; Piura, E.; Vickers, E.; Cunningham, M.; Larsson, O.; Fazli, L.; Pollak, M. Insulin receptor expression by human prostate cancers. Prostate 2009, 69, 33-40. [CrossRef]

151. Kalli, K.R.; Falowo, O.I.; Bale, L.K.; Zschunke, M.A.; Roche, P.C.; Conover, C.A. Functional insulin receptors on human epithelial ovarian carcinoma cells: Implications for IGF-II mitogenic signaling. Endocrinology 2002, 143, 3259-3267. [CrossRef]

152. Law, J.H.; Habibi, G.; Hu, K.; Masoudi, H.; Wang, M.Y.; Stratford, A.L.; Park, E.; Gee, J.M.W.; Finlay, P.; Jones, H.E.; et al. Phosphorylated insulin-like growth factor-i/insulin receptor is present in all breast cancer subtypes and is related to poor survival. Cancer Res. 2008, 68, 10238-10246. [CrossRef] [PubMed]

153. Sanaki, Y.; Nagata, R.; Kizawa, D.; Léopold, P.; Igaki, T. Hyperinsulinemia Drives Epithelial Tumorigenesis by Abrogating Cell Competition. Dev. Cell 2020, 53, 379-389.e5. [CrossRef] [PubMed]

154. Bar, R.S.; Kahn, C.R.; Koren, H.S. Insulin inhibition of antibody-dependent cytoxicity and insulin receptors in macrophages. Nature 1977, 265, 632-635. [CrossRef] [PubMed]

155. Costa Rosa, L.F.; Safi, D.A.; Cury, Y.; Curi, R.; Rosa, L.F.B.P.C.; Safi, D.A.; Cury, Y.; Curit, R. The effect of insulin on macrophage metabolism and function. Cell Biochem. Funct. 1996, 14, 33-42. [CrossRef]

156. Tada Iida, K.; Shimano, H.; Kawakami, Y.; Sone, H.; Toyoshima, H.; Suzuki, S.; Asano, T.; Okuda, Y.; Yamada, N. Insulin Upregulates Tumor Necrosis Factor- $\alpha$ Production in Macrophages through an Extracellular-regulated Kinase-dependent Pathway. J. Biol. Chem. 2001, 276, 32531-32537. [CrossRef]

157. Iida, K.T. Insulin Inhibits Apoptosis of Macrophage Cell Line, THP-1 Cells, via Phosphatidylinositol-3-Kinase-Dependent Pathway. Arterioscler. Thromb. Vasc. Biol. 2002, 22, 380-386. [CrossRef]

158. Senokuchi, T.; Liang, C.-P.; Seimon, T.A.; Han, S.; Matsumoto, M.; Banks, A.S.; Paik, J.-H.; DePinho, R.A.; Accili, D.; Tabas, I.; et al. Forkhead transcription factors (FoxOs) promote apoptosis of insulin-resistant macrophages during cholesterol-induced endoplasmic reticulum stress. Diabetes 2008, 57, 2967-2976. [CrossRef] 
159. Su, D.; Coudriet, G.M.; Hyun Kim, D.; Lu, Y.; Perdomo, G.; Qu, S.; Slusher, S.; Tse, H.M.; Piganelli, J.; Giannoukakis, N.; et al. FoxO1 links insulin resistance to proinflammatory cytokine IL-1beta production in macrophages. Diabetes 2009, 58, $2624-2633$. [CrossRef]

160. Yan, H.; Ma, Y.; Li, Y.; Zheng, X.; Lv, P.; Zhang, Y.; Li, J.; Ma, M.; Zhang, L.; Li, C.; et al. Insulin inhibits inflammation and promotes atherosclerotic plaque stability via PI3K-Akt pathway activation. Immunol. Lett. 2015, 170, 7-14. [CrossRef]

161. Kratz, M.; Coats, B.R.; Hisert, K.B.; Hagman, D.; Mutskov, V.; Peris, E.; Schoenfelt, K.Q.; Kuzma, J.N.; Larson, I.; Billing, P.S.; et al. Metabolic dysfunction drives a mechanistically distinct proinflammatory phenotype in adipose tissue macrophages. Cell Metab. 2014, 20, 614-625. [CrossRef]

162. Park, Y.M.; Kashyap, S.R.; Major, J.A.; Silverstein, R.L. Insulin promotes macrophage foam cell formation: Potential implications in diabetes-related atherosclerosis. Lab. Investig. 2012, 92, 1171-1180. [CrossRef]

163. Thibaut, R.; Gage, M.C.; Pineda-Torra, I.; Chabrier, G.; Venteclef, N.; Alzaid, F. Liver macrophages and inflammation in physiology and physiopathology of non-alcoholic fatty liver disease. FEBS J. 2021, febs.15877. [CrossRef]

164. Russell-jones, D.L.; Bates, A.T.; Umpleby, A.M.; Hennessy, T.R.; Bowes, S.B.; Hopkins, K.D.; Jackson, N.; Kelly, J.; Shojaee-moradie, F.; Jones, R.H.; et al. A comparison of the effects of IGF-I and insulin on glucose metabolism, fat metabolism and the cardiovascular system in normal human volunteers. Eur. J. Clin. Investig. 1995, 25, 403-411. [CrossRef]

165. Chang, H.R.; Kim, H.J.; Xu, X.; Ferrante, A.W. Macrophage and adipocyte IGF1 maintain adipose tissue homeostasis during metabolic stresses. Obesity 2016, 24, 172-183. [CrossRef]

166. Spadaro, O.; Camell, C.D.; Bosurgi, L.; Nguyen, K.Y.; Youm, Y.H.; Rothlin, C.V.; Dixit, V.D. IGF1 Shapes Macrophage Activation in Response to Immunometabolic Challenge. Cell Rep. 2017, 19, 225-234. [CrossRef]

167. Rom, W.N.; Pääkkö, P. Activated alveolar macrophages express the insulin-like growth factor-I receptor. Am. J. Respir. Cell Mol. Biol. 1991, 4, 432-439. [CrossRef]

168. Adams, T.E.; Epa, V.C.; Garrett, T.P.J.; Ward, C.W. Structure and function of the type 1 insulin-like growth factor receptor. Cell. Mol. Life Sci. C 2000, 57, 1050-1093. [CrossRef]

169. Lawrence, M.C.; McKern, N.M.; Ward, C.W. Insulin receptor structure and its implications for the IGF-1 receptor. Curr. Opin. Struct. Biol. 2007, 17, 699-705. [CrossRef]

170. Tsuruzoe, K.; Emkey, R.; Kriauciunas, K.M.; Ueki, K.; Kahn, C.R. Insulin Receptor Substrate 3 (IRS-3) and IRS-4 Impair IRS-1- and IRS-2-Mediated Signaling. Mol. Cell. Biol. 2001, 21, 26-38. [CrossRef]

171. Roith, D.L. The insulin-like growth factor system. Exp. Diabesity Res. 2003, 4, 205-212. [CrossRef]

172. Murphy, N.; Carreras-Torres, R.; Song, M.; Chan, A.T.; Martin, R.M.; Papadimitriou, N.; Dimou, N.; Tsilidis, K.K.; Banbury, B.; Bradbury, K.E.; et al. Circulating Levels of Insulin-like Growth Factor 1 and Insulin-like Growth Factor Binding Protein 3 Associate With Risk of Colorectal Cancer Based on Serologic and Mendelian Randomization Analyses. Gastroenterology 2020, 158, 1300-1312.e20. [CrossRef]

173. Murphy, N.; Knuppel, A.; Papadimitriou, N.; Martin, R.M.; Tsilidis, K.K.; Smith-Byrne, K.; Fensom, G.; Perez-Cornago, A.; Travis, R.C.; Key, T.J.; et al. Insulin-like growth factor-1, insulin-like growth factor-binding protein-3, and breast cancer risk: Observational and Mendelian randomization analyses with $\sim 430000$ women. Ann. Oncol. Off. J. Eur. Soc. Med. Oncol. 2020, 31, 641-649. [CrossRef] [PubMed]

174. Párrizas, M.; Saltiel, A.R.; LeRoith, D. Insulin-like growth factor 1 inhibits apoptosis using the phosphatidylinositol 3'-kinase and mitogen-activated protein kinase pathways. J. Biol. Chem. 1997, 272, 154-161. [CrossRef] [PubMed]

175. Sekharam, M.; Zhao, H.; Sun, M.; Fang, Q.; Zhang, Q.; Yuan, Z.; Dan, H.C.; Boulware, D.; Cheng, J.Q.; Coppola, D. Insulin-like growth factor 1 receptor enhances invasion and induces resistance to apoptosis of colon cancer cells through the Akt/Bcl-x(L) pathway. Cancer Res. 2003, 63, 7708-7716. [PubMed]

176. Kaleko, M.; Rutter, W.J.; Miller, A.D. Overexpression of the human insulinlike growth factor I receptor promotes ligand-dependent neoplastic transformation. Mol. Cell. Biol. 1990, 10, 464-473. [CrossRef] [PubMed]

177. Arkins, S.; Rebeiz, N.; Biragyn, A.; Reese, D.L.; Kelley, K.W. Murine macrophages express abundant insulin-like growth factor-I class I Ea and Eb transcripts. Endocrinology 1993, 133, 2334-2343. [CrossRef] [PubMed]

178. Martinez, F.O.; Gordon, S.; Locati, M.; Mantovani, A. Transcriptional profiling of the human monocyte-to-macrophage differentiation and polarization: New molecules and patterns of gene expression. J. Immunol. 2006, 177, 7303-7311. [CrossRef]

179. Renier, G.; Clément, I.; Desfaits, A.C.; Lambert, A. Direct stimulatory effect of insulin-like growth factor-I on monocyte and macrophage tumor necrosis factor-alpha production. Endocrinology 1996, 137, 4611-4618. [CrossRef]

180. Hochberg, Z.; Hertz, P.; Maor, G.; Oiknine, J.; Aviram, M. Growth hormone and insulin-like growth factor-I increase macrophage uptake and degradation of low density lipoprotein. Endocrinology 1992, 131, 430-435. [CrossRef]

181. Spadaro, O.; Goldberg, E.L.; Camell, C.D.; Youm, Y.H.; Kopchick, J.J.; Nguyen, K.Y.; Bartke, A.; Sun, L.Y.; Dixit, V.D. Growth Hormone Receptor Deficiency Protects against Age-Related NLRP3 Inflammasome Activation and Immune Senescence. Cell Rep. 2016, 14, 1571-1580. [CrossRef]

182. Scotece, M.; Conde, J.; López, V.; Lago, F.; Pino, J.; Gómez-Reino, J.J.; Gualillo, O. Adiponectin and leptin: New targets in inflammation. Basic Clin. Pharmacol. Toxicol. 2014, 114, 97-102. [CrossRef] [PubMed]

183. Al-Suhaimi, E.A.; Shehzad, A. Leptin, resistin and visfatin: The missing link between endocrine metabolic disorders and immunity. Eur. J. Med. Res. 2013, 18, 12. [CrossRef] [PubMed] 
184. Rosenbaum, M.; Leibel, R.L. 20 years of leptin: Role of leptin in energy homeostasis in humans. J. Endocrinol. 2014, 223, T83-T96. [CrossRef]

185. O'Rourke, L.; Yeaman, S.J.; Shepherd, P.R. Insulin and leptin acutely regulate cholesterol ester metabolism in macrophages by novel signaling pathways. Diabetes 2001, 50, 955-961. [CrossRef] [PubMed]

186. Zhang, F.; Chen, Y.; Heiman, M.; DiMarchi, R. Leptin: Structure, Function and Biology; Academic Press: Cambridge, MA, USA, 2005; Volume 71, pp. 345-372. ISBN 0083-6729.

187. Pelleymounter, M.A.; Cullen, M.J.; Baker, M.B.; Hecht, R.; Winters, D.; Boone, T.; Collins, F. Effects of the obese gene product on body weight regulation in ob/ob mice. Science 1995, 269, 540-543. [CrossRef]

188. Lin, T.-C.; Hsiao, M. Leptin and Cancer: Updated Functional Roles in Carcinogenesis, Therapeutic Niches, and Developments. Int. J. Mol. Sci. 2021, 22, 2870. [CrossRef]

189. Vuletic, M.S.; Milosevic, V.S.; Jancic, S.A.; Zujovic, J.T.; Krstic, M.S.; Vukmirovic, F.C. Clinical significance of Leptin receptor (LEPR) and Endoglin (CD105) expressions in colorectal adenocarcinoma. J. BUON 2019, 24, 2448-2457.

190. Han, G.; Li, Y.; Cao, Y.; Yue, Z.; Zhang, Y.; Wang, L.; Liu, J. Overexpression of leptin receptor in human glioblastoma: Correlation with vasculogenic mimicry and poor prognosis. Oncotarget 2017, 8, 58163-58171. [CrossRef] [PubMed]

191. Newman, G.; Gonzalez-Perez, R.R. Leptin-cytokine crosstalk in breast cancer. Mol. Cell. Endocrinol. 2014, 382, 570-582. [CrossRef]

192. Chen, C.; Chang, Y.-C.; Lan, S.M.; Breslin, M. Leptin stimulates ovarian cancer cell growth and inhibits apoptosis by increasing cyclin D1 and Mcl-1 expression via the activation of the MEK/ERK1/2 and PI3K/Akt signaling pathways Corrigendum in /10.3892/ijo.2016.3564. Int. J. Oncol. 2013, 42, 1113-1119. [CrossRef]

193. Babic, A.; Bao, Y.; Qian, Z.R.; Yuan, C.; Giovannucci, E.L.; Aschard, H.; Kraft, P.; Amundadottir, L.T.; Stolzenberg-Solomon, R.; Morales-Oyarvide, V.; et al. Pancreatic Cancer Risk Associated with Prediagnostic Plasma Levels of Leptin and Leptin Receptor Genetic Polymorphisms. Cancer Res. 2016, 76, 7160-7167. [CrossRef] [PubMed]

194. Atoum, M.F.; Alzoughool, F.; Al-Hourani, H. Linkage Between Obesity Leptin and Breast Cancer. Breast Cancer 2020, 14, 1178223419898458. [CrossRef] [PubMed]

195. Tartaglia, L.A. The leptin receptor. J. Biol. Chem. 1997, 272, 6093-6096. [CrossRef]

196. Loffreda, S.; Yang, S.Q.; Lin, H.Z.; Karp, C.L.; Brengman, M.L.; Wang, D.J.; Klein, A.S.; Bulkley, G.B.; Bao, C.; Noble, P.W.; et al. Leptin regulates proinflammatory immune responses. FASEB J. 1998, 12, 57-65. [CrossRef]

197. Gainsford, T.; Willson, T.A.; Metcalf, D.; Handman, E.; McFarlane, C.; Ng, A.; Nicola, N.A.; Alexander, W.S.; Hilton, D.J. Leptin can induce proliferation, differentiation, and functional activation of hemopoietic cells. Proc. Natl. Acad. Sci. USA 1996, 93, 14564-14568. [CrossRef] [PubMed]

198. Santos-Alvarez, J.; Goberna, R.; Sánchez-Margalet, V. Human leptin stimulates proliferation and activation of human circulating monocytes. Cell. Immunol. 1999, 194, 6-11. [CrossRef] [PubMed]

199. Kiguchi, N.; Maeda, T.; Kobayashi, Y.; Fukazawa, Y.; Kishioka, S. Leptin enhances CC-chemokine ligand expression in cultured murine macrophage. Biochem. Biophys. Res. Commun. 2009, 384, 311-315. [CrossRef] [PubMed]

200. Tsiotra, P.C.; Boutati, E.; Dimitriadis, G.; Raptis, S.A. High insulin and leptin increase resistin and inflammatory cytokine production from human mononuclear cells. Biomed Res. Int. 2013, 2013, 487081. [CrossRef] [PubMed]

201. Acedo, S.C.; Gambero, S.; Cunha, F.G.P.; Lorand-Metze, I.; Gambero, A. Participation of leptin in the determination of the macrophage phenotype: An additional role in adipocyte and macrophage crosstalk. Vitr. Cell. Dev. Biol.-Anim. 2013, 49, 473-478. [CrossRef] [PubMed]

202. Zhou, Y.; Rui, L. Leptin signaling and leptin resistance. Front. Med. 2013, 7, 207-222. [CrossRef]

203. Maya-Monteiro, C.M.; Almeida, P.E.; D'Ávila, H.; Martins, A.S.; Rezende, A.P.; Castro-Faria-Neto, H.; Bozza, P.T. Leptin induces macrophage lipid body formation by a phosphatidylinositol 3-kinase- and mammalian target of rapamycin-dependent mechanism. J. Biol. Chem. 2008, 283, 2203-2210. [CrossRef]

204. Minokoshi, Y.; Kim, Y.-B.; Peroni, O.D.; Fryer, L.G.D.; Müller, C.; Carling, D.; Kahn, B.B. Leptin stimulates fatty-acid oxidation by activating AMP-activated protein kinase. Nature 2002, 415, 339-343. [CrossRef]

205. Bernotiene, E.; Palmer, G.; Gabay, C. The role of leptin in innate and adaptive immune responses. Arthritis Res. Ther. 2006, 8, 217. [CrossRef]

206. Cerdá-Reverter, J.M.; Larhammar, D. Neuropeptide Y family of peptides: Structure, anatomical expression, function, and molecular evolution. Biochem. Cell Biol. 2000, 78, 371-392. [CrossRef]

207. Simpson, K.A.; Martin, N.M.; Bloom, S.R. Hypothalamic regulation of food intake and clinical therapeutic applications. Arq. Bras. Endocrinol. Metabol. 2009, 53, 120-128. [CrossRef] [PubMed]

208. Taylor, I.L. Distribution and release of peptide YY in dog measured by specific radioimmunoassay. Gastroenterology 1985, 88, 731-737. [CrossRef]

209. Ekblad, E.; Sundler, F. Distribution of pancreatic polypeptide and peptide YY. Peptides 2002, 23, 251-261. [CrossRef]

210. Degen, L.; Oesch, S.; Casanova, M.; Graf, S.; Ketterer, S.; Drewe, J.; Beglinger, C. Effect of peptide YY3-36 on food intake in humans. Gastroenterology 2005, 129, 1430-1436. [CrossRef] [PubMed]

211. Mentlein, R.; Dahms, P.; Grandt, D.; Krüger, R. Proteolytic processing of neuropeptide Y and peptide YY by dipeptidyl peptidase IV. Regul. Pept. 1993, 49, 133-144. [CrossRef]

212. Ballantyne, G.H. Peptide YY(1-36) and Peptide YY(3-36): Part I. Distribution, release and actions part II. Changes after gastointestinal and bariatric surgery will appear in the next issue (June 2006). Obes. Surg. 2006, 16, 651-658. [CrossRef] 
213. Bromée, T.; Sjödin, P.; Fredriksson, R.; Boswell, T.; Larsson, T.A.; Salaneck, E.; Zoorob, R.; Mohell, N.; Larhammar, D. Neuropeptide Y-family receptors $Y 6$ and $Y 7$ in chicken: Cloning, pharmacological characterization, tissue distribution and conserved synteny with human chromosome region. FEBS J. 2006, 273, 2048-2063. [CrossRef]

214. Grandt, D.; Schimiczek, M.; Rascher, W.; Feth, F.; Shively, J.; Lee, T.D.; Davis, M.T.; Reeve, J.R.; Michel, M.C. Neuropeptide Y $3-36$ is an endogenous ligand selective for $\mathrm{Y} 2$ receptors. Regul. Pept. 1996, 67, 33-37. [CrossRef]

215. Macia, L.; Rao, P.T.; Wheway, J.; Sierro, F.; Mackay, F.; Herzog, H. Y1 signalling has a critical role in allergic airway inflammation. Immunol. Cell Biol. 2011, 89, 882-888. [CrossRef] [PubMed]

216. Smith, R.M.; Klein, R.; Kruzliak, P.; Zulli, A. Role of Peptide YY in blood vessel function and atherosclerosis in a rabbit model. Clin. Exp. Pharmacol. Physiol. 2015, 42, 648-652. [CrossRef]

217. Tseng, W.W.; Liu, C.D. Peptide YY and cancer: Current findings and potential clinical applications. Peptides 2002, 23, 389-395. [CrossRef]

218. Li, J.; Tian, Y.; Wu, A. Neuropeptide Y receptors: A promising target for cancer imaging and therapy. Regen. Biomater. 2015, 2, 215-219. [CrossRef]

219. Tilan, J.; Kitlinska, J. Neuropeptide Y (NPY) in tumor growth and progression: Lessons learned from pediatric oncology. Neuropeptides 2016, 55, 55-66. [CrossRef]

220. De La Fuente, M.; Bernaez, I.; Del Rio, M.; Hernanz, A. Stimulation of murine peritoneal macrophage functions by neuropeptide $\mathrm{Y}$ and peptide YY. Involvement of protein kinase C. Immunology 1993, 80, 259-25965.

221. Mitić, K.; Stanojević, S.; Kuštrimović, N.; Vujić, V.; Dimitrijević, M. Neuropeptide y modulates functions of inflammatory cells in the rat: Distinct role for Y1, Y2 and Y5 receptors. Peptides 2011, 32, 1626-1633. [CrossRef]

222. Stanojević, S.; Vujić, V.; Kovačević-Jovanović, V.; Mitić, K.; Kosec, D.; von Hörsten, S.; Dimitrijević, M. Age-related effect of peptide YY (PYY) on paw edema in the rat: The function of Y1 receptors on inflammatory cells. Exp. Gerontol. 2006, 41, 793-799. [CrossRef]

223. Dimitrijević, M.; Stanojević, S. The intriguing mission of neuropeptide y in the immune system. Amino Acids 2013, 45, 41-53. [CrossRef]

224. Bedoui, S.; Kromer, A.; Gebhardt, T.; Jacobs, R.; Raber, K.; Dimitrijevic, M.; Heine, J.; von Hörsten, S. Neuropeptide Y receptorspecifically modulates human neutrophil function. J. Neuroimmunol. 2008, 195, 88-95. [CrossRef]

225. Nave, H.; Bedoui, S.; Moenter, F.; Steffens, J.; Felies, M.; Gebhardt, T.; Straub, R.H.; Pabst, R.; Dimitrijevic, M.; Stanojevic, S.; et al. Reduced tissue immigration of monocytes by neuropeptide $\mathrm{Y}$ during endotoxemia is associated with $\mathrm{Y} 2$ receptor activation. $J$. Neuroimmunol. 2004, 155, 1-12. [CrossRef]

226. Muk, T.; Stensballe, A.; Pankratova, S.; Nguyen, D.N.; Brunse, A.; Sangild, P.T.; Jiang, P.-P. Rapid Proteome Changes in Plasma and Cerebrospinal Fluid Following Bacterial Infection in Preterm Newborn Pigs. Front. Immunol. 2019, 10, 2651. [CrossRef]

227. Macia, L.; Yulyaningsih, E.; Pangon, L.; Nguyen, A.D.; Lin, S.; Shi, Y.C.; Zhang, L.; Bijker, M.; Grey, S.; Mackay, F.; et al. Neuropeptide Y1 receptor in immune cells regulates inflammation and insulin resistance associated with diet-induced obesity. Diabetes 2012, 61, 3228-3238. [CrossRef] [PubMed]

228. Puerto, M.; Guayerbas, N.; Álvarez, P.; De La Fuente, M. Modulation of neuropeptide Y and norepinephrine on several leucocyte functions in adult, old and very old mice. J. Neuroimmunol. 2005, 165, 33-40. [CrossRef]

229. Ferreira, R.; Xapelli, S.; Santos, T.; Silva, A.P.; Cristóvão, A.; Cortes, L.; Malva, J.O. Neuropeptide Y modulation of interleukin-1 $\beta$ (IL-1ß)-induced nitric oxide production in microglia. J. Biol. Chem. 2010, 285, 41921-41934. [CrossRef] [PubMed]

230. Zhou, J.R.; Xu, Z.; Jiang, C.L. Neuropeptide Y promotes TGF- 31 production in RAW264.7 cells by activating PI3K pathway via Y1 receptor. Neurosci. Bull. 2008, 24, 155-159. [CrossRef]

231. Gao, B.; Li, L.; Zhu, P.; Zhang, M.; Hou, L.; Sun, Y.; Liu, X.; Peng, X.; Gu, Y. Chronic administration of methamphetamine promotes atherosclerosis formation in ApoE-/- knockout mice fed normal diet. Atherosclerosis 2015, 243, 268-277. [CrossRef]

232. De la Fuente, M.; Del Río, M.; Medina, S. Changes with aging in the modulation by neuropeptide $\mathrm{Y}$ of murine peritoneal macrophage functions. J. Neuroimmunol. 2001, 116, 156-167. [CrossRef]

233. Hernanz, A.; Tato, E.; De la Fuente, M.; De Miguel, E.; Arnalich, F. Differential effects of gastrin-releasing peptide, neuropeptide $Y$ somatostatin and vasoactive intestinal peptide on interleukin- $1 \beta$, interleukin- 6 and tumor necrosis factor- $\alpha$ production by whole blood cells from healthy young and old subjects. J. Neuroimmunol. 1996, 71, 25-30. [CrossRef]

234. Cheng, Y.; Tang, X.Y.; Li, Y.X.; Zhao, D.D.; Cao, Q.H.; Wu, H.X.; Yang, H.B.; Hao, K.; Yang, Y. Depression-induced neuropeptide y secretion promotes prostate cancer growth by recruiting myeloid cells. Clin. Cancer Res. 2019, 25, 2621-2632. [CrossRef] [PubMed]

235. Barakat, R.; Oakley, O.; Kim, H.; Jin, J.; Ko, C.M.J. Extra-gonadal sites of estrogen biosynthesis and function. BMB Rep. 2016, 49, 488-496. [CrossRef] [PubMed]

236. Cui, J.; Shen, Y.; Li, R. Estrogen synthesis and signaling pathways during aging: From periphery to brain. Trends Mol. Med. 2013, 19, 197-209. [CrossRef]

237. Xu, Y.; López, M. Central regulation of energy metabolism by estrogens. Mol. Metab. 2018, 15, 104-115. [CrossRef] [PubMed]

238. Jia, M.; Dahlman-Wright, K.; Gustafsson, J.Å. Estrogen receptor alpha and beta in health and disease. Best Pract. Res. Clin. Endocrinol. Metab. 2015, 29, 557-568. [CrossRef]

239. Prossnitz, E.R.; Arterburn, J.B.; Sklar, L.A. GPR30: A G protein-coupled receptor for estrogen. Mol. Cell. Endocrinol. 2007, 265-266, 138-142. [CrossRef] 
240. Murphy, A.J.; Guyre, P.M.; Wira, C.R.; Pioli, P.A. Estradiol regulates expression of estrogen receptor ER $\alpha 46$ in human macrophages. PLoS ONE 2009, 4, e5539. [CrossRef] [PubMed]

241. Toniolo, A.; Fadini, G.P.; Tedesco, S.; Cappellari, R.; Vegeto, E.; Maggi, A.; Avogaro, A.; Bolego, C.; Cignarella, A. Alternative Activation of Human Macrophages Is Rescued by Estrogen Treatment In Vitro and Impaired by Menopausal Status. J. Clin. Endocrinol. Metab. 2015, 100, E50-E58. [CrossRef]

242. Rettew, J.A.; McCall, S.H.; Marriott, I. GPR30/GPER-1 mediates rapid decreases in TLR4 expression on murine macrophages. Mol. Cell. Endocrinol. 2010, 328, 87-92. [CrossRef]

243. Vegeto, E.; Bonincontro, C.; Pollio, G.; Sala, A.; Viappiani, S.; Nardi, F.; Brusadelli, A.; Viviani, B.; Ciana, P.; Maggi, A. Estrogen prevents the lipopolysaccharide-induced inflammatory response in microglia. J. Neurosci. 2001, 21, 1809-1818. [CrossRef]

244. Pelekanou, V.; Kampa, M.; Kiagiadaki, F.; Deli, A.; Theodoropoulos, P.; Agrogiannis, G.; Patsouris, E.; Tsapis, A.; Castanas, E.; Notas, G. Estrogen anti-inflammatory activity on human monocytes is mediated through cross-talk between estrogen receptor ER $\alpha 36$ and GPR30/GPER1. J. Leukoc. Biol. 2016, 99, 333-347. [CrossRef]

245. Leeners, B.; Geary, N.; Tobler, P.N.; Asarian, L. Ovarian hormones and obesity. Hum. Reprod. Update 2017, 23, 300-321. [CrossRef]

246. Matarrese, P.; Mattia, G.; Pagano, M.T.; Pontecorvi, G.; Ortona, E.; Malorni, W.; Carè, A. The sex-related interplay between tme and cancer: On the critical role of estrogen, micrornas and autophagy. Cancers 2021, 13, 3287. [CrossRef]

247. Cook, M.B.; Dawsey, S.M.; Freedman, N.D.; Inskip, P.D.; Wichner, S.M.; Quraishi, S.M.; Devesa, S.S.; McGlynn, K.A. Sex disparities in cancer incidence by period and age. Cancer Epidemiol. Biomarkers Prev. 2009, 18, 1174-1182. [CrossRef] [PubMed]

248. Cook, M.B.; McGlynn, K.A.; Devesa, S.S.; Freedman, N.D.; Anderson, W.F. Sex disparities in cancer mortality and survival. Cancer Epidemiol. Biomarkers Prev. 2011, 20, 1629-1637. [CrossRef] [PubMed]

249. Wang, T.; Jin, J.; Qian, C.; Lou, J.; Lin, J.; Xu, A.; Xia, K.; Jin, L.; Liu, B.; Tao, H.; et al. Estrogen/ER in anti-tumor immunity regulation to tumor cell and tumor microenvironment. Cancer Cell Int. 2021, 21, 295. [CrossRef] [PubMed]

250. Xiao, L.; Luo, Y.; Tai, R.; Zhang, N. Estrogen receptor $\beta$ suppresses inflammation and the progression of prostate cancer. Mol. Med. Rep. 2019, 49, 3555-3563. [CrossRef]

251. Yeh, C.R.; Slavin, S.; Da, J.; Hsu, I.; Luo, J.; Xiao, G.Q.; Ding, J.; Chou, F.J.; Yeh, S. Estrogen receptor $\alpha$ in cancer associated fibroblasts suppresses prostate cancer invasion via reducing CCL5, IL6 and macrophage infiltration in the tumor microenvironment. Mol. Cancer 2016, 15, 7. [CrossRef]

252. Svoronos, N.; Perales-Puchalt, A.; Allegrezza, M.J.; Rutkowski, M.R.; Payne, K.K.; Tesone, A.J.; Nguyen, J.M.; Curiel, T.J.; Cadungog, M.G.; Singhal, S.; et al. Tumor cell-independent estrogen signaling drives disease progression through mobilization of myeloid-derived suppressor cells. Cancer Discov. 2017, 7, 72-85. [CrossRef] [PubMed]

253. Gabrilovich, D.I.; Ostrand-Rosenberg, S.; Bronte, V. Coordinated regulation of myeloid cells by tumours. Nat. Rev. Immunol. 2012, 12, 253-268. [CrossRef] [PubMed]

254. Pepe, G.; Braga, D.; Renzi, T.A.; Villa, A.; Bolego, C.; D’Avila, F.; Barlassina, C.; Maggi, A.; Locati, M.; Vegeto, E. Self-renewal and phenotypic conversion are the main physiological responses of macrophages to the endogenous estrogen surge. Sci. Rep. 2017, 7, 44270. [CrossRef]

255. Pepe, G.; Locati, M.; Della Torre, S.; Mornata, F.; Cignarella, A.; Maggi, A.; Vegeto, E. The estrogen-macrophage interplay in the homeostasis of the female reproductive tract. Hum. Reprod. Update 2018, 24, 652-672. [CrossRef]

256. Zheng, C.; Yang, Q.; Cao, J.; Xie, N.; Liu, K.; Shou, P.; Qian, F.; Wang, Y.; Shi, Y. Local proliferation initiates macrophage accumulation in adipose tissue during obesity. Cell Death Dis. 2016, 7, e2167. [CrossRef] [PubMed]

257. Jenkins, S.J.; Ruckerl, D.; Cook, P.C.; Jones, L.H.; Finkelman, F.D.; van Rooijen, N.; MacDonald, A.S.; Allen, J.E. Local Macrophage Proliferation, Rather than Recruitment from the Blood, Is a Signature of TH2 Inflammation. Science 2011, 332, $1284-1288$. [CrossRef]

258. Robbins, C.S.; Hilgendorf, I.; Weber, G.F.; Theurl, I.; Iwamoto, Y.; Figueiredo, J.-L.; Gorbatov, R.; Sukhova, G.K.; Gerhardt, L.M.S.; Smyth, D.; et al. Local proliferation dominates lesional macrophage accumulation in atherosclerosis. Nat. Med. 2013, 19, 1166-1172. [CrossRef] [PubMed]

259. Lhoták, Š.; Gyulay, G.; Cutz, J.; Al-Hashimi, A.; Trigatti, B.L.; Richards, C.D.; Igdoura, S.A.; Steinberg, G.R.; Bramson, J.; Ask, K.; et al. Characterization of Proliferating Lesion-Resident Cells During All Stages of Atherosclerotic Growth. J. Am. Heart Assoc. 2016, 5, e003945. [CrossRef] [PubMed]

260. Gage, M.C.; Bécares, N.; Louie, R.; Waddington, K.E.; Zhang, Y.; Tittanegro, T.H.; Rodríguez-Lorenzo, S.; Jathanna, A.; Pourcet, B.; Pello, O.M.; et al. Disrupting LXR $\alpha$ phosphorylation promotes FoxM1 expression and modulates atherosclerosis by inducing macrophage proliferation. Proc. Natl. Acad. Sci. USA 2018, 115, E6556-E6565. [CrossRef] [PubMed]

261. Campbell, L.; Emmerson, E.; Williams, H.; Saville, C.R.; Krust, A.; Chambon, P.; Mace, K.A.; Hardman, M.J. Estrogen ReceptorAlpha Promotes Alternative Macrophage Activation during Cutaneous Repair. J. Investig. Dermatol. 2014, 134, $2447-2457$. [CrossRef]

262. Villa, A.; Rizzi, N.; Vegeto, E.; Ciana, P.; Maggi, A. Estrogen accelerates the resolution of inflammation in macrophagic cells. Sci. Rep. 2015, 5, 1-14. [CrossRef] [PubMed]

263. Yang, W.; Lu, Y.; Xu, Y.; Xu, L.; Zheng, W.; Wu, Y.; Li, L.; Shen, P. Estrogen represses hepatocellular carcinoma (HCC) Growth via Inhibiting Alternative Activation of Tumor-associated Macrophages (TAMs). J. Biol. Chem. 2012, 287, 40140-40149. [CrossRef] 
264. Kou, X.-X.; Li, C.-S.; He, D.-Q.; Wang, X.-D.; Hao, T.; Meng, Z.; Zhou, Y.-H.; Gan, Y.-H. Estradiol Promotes M1-like Macrophage Activation through Cadherin-11 To Aggravate Temporomandibular Joint Inflammation in Rats. J. Immunol. 2015, 194, $2810-2818$. [CrossRef]

265. Attia, D.M.A.; Ederveen, A.G.H. Opposing roles of ER $\alpha$ and ER $\beta$ in the genesis and progression of adenocarcinoma in the rat ventral prostate. Prostate 2012, 72, 1013-1022. [CrossRef]

266. Calippe, B.; Douin-Echinard, V.; Delpy, L.; Laffargue, M.; Lélu, K.; Krust, A.; Pipy, B.; Bayard, F.; Arnal, J.-F.; Guéry, J.-C.; et al. $17 \beta$-Estradiol Promotes TLR4-Triggered Proinflammatory Mediator Production through Direct Estrogen Receptor $\alpha$ Signaling in Macrophages In Vivo. J. Immunol. 2010, 185, 1169-1176. [CrossRef] [PubMed]

267. Gregory, M.S.; Duffner, L.A.; Faunce, D.E.; Kovacs, E.J. Estrogen mediates the sex difference in post-burn immunosuppression. J. Endocrinol. 2000, 164, 129-138. [CrossRef] [PubMed]

268. Morishita, M.; Miyagi, M.; Iwamoto, Y. Effects of Sex Hormones on Production of Interleukin-1 by Human Peripheral Monocytes. J. Periodontol. 1999, 70,757-760. [CrossRef]

269. Ruh, M.F.; Bi, Y.; D’Alonzo, R.; Bellone, C.J. Effect of estrogens on IL-1 $\beta$ promoter activity. J. Steroid Biochem. Mol. Biol. 1998, 66, 203-210. [CrossRef]

270. Ralston, S.H.; Russell, R.G.G.; Gowen, M. Estrogen inhibits release of tumor necrosis factor from peripheral blood mononuclear cells in postmenopausal women. J. Bone Miner. Res. 1990, 5, 983-988. [CrossRef] [PubMed]

271. Woodfork, K.A.; Schuller, K.C.; Huffman, L.J. Cytokine and nitric oxide release by J774A.1 macrophages is not regulated by estradiol. Life Sci. 2001, 69, 2287-2294. [CrossRef]

272. Kassem, M.; Khosla, S.; Spelsberg, T.C.; Riggs, B.L. Cytokine production in the bone marrow microenvironment: Failure to demonstrate estrogen regulation in early postmenopausal women. J. Clin. Endocrinol. Metab. 1996, 81, 513-518. [CrossRef]

273. Pfeilschifter, J.; Köditz, R.; Pfohl, M.; Schatz, H. Changes in proinflammatory cytokine activity after menopause. Endocr. Rev. 2002, 23, 90-119. [CrossRef]

274. Svensson, S.; Abrahamsson, A.; Rodriguez, G.V.; Olsson, A.K.; Jensen, L.; Cao, Y.; Dabrosin, C. CCL2 and CCL5 are novel therapeutic targets for estrogen-dependent breast cancer. Clin. Cancer Res. 2015, 21, 3794-3805. [CrossRef] [PubMed]

275. Handelsman, D.J. Androgen Physiology, Pharmacology, and Abuse. In Endocrinology: Adult and Pediatric; Elsevier Inc.: Amsterdam, The Netherlands, 2015; pp. 2368-2393. ISBN 9780323189071.

276. Grino, P.B.; Griffin, J.E.; Wilson, J.D. Testosterone at High Concentrations Interacts with the Human Androgen Receptor Similarly to Dihydrotestosterone. Endocrinology 1990, 126, 1165-1172. [CrossRef] [PubMed]

277. Chang, C.; Saltzman, A.; Yeh, S.; Young, W.; Keller, E.; Lee, H.J.; Wang, C.; Mizokami, A. Androgen receptor: An overview. Crit. Rev. Eukaryot. Gene Expr. 1995, 5, 97-125. [CrossRef]

278. Lösel, R.M.; Falkenstein, E.; Feuring, M.; Schultz, A.; Tillmann, H.C.; Rossol-Haseroth, K.; Wehling, M. Nongenomic steroid action: Controversies, questions, and answers. Physiol. Rev. 2003, 83, 965-1016. [CrossRef] [PubMed]

279. Fui, M.N.T.; Dupuis, P.; Grossmann, M. Lowered testosterone in male obesity: Mechanisms, morbidity and management. Asian J. Androl. 2014, 16, 223-231. [CrossRef]

280. Pasquali, R. Obesity and androgens: Facts and perspectives. Fertil. Steril. 2006, 85, 1319-1340. [CrossRef]

281. Zhang, L.J.; Xiong, Y.; Nilubol, N.; He, M.; Bommareddi, S.; Zhu, X.; Jia, L.; Xiao, Z.; Park, J.-W.; Xu, X.; et al. Testosterone regulates thyroid cancer progression by modifying tumor suppressor genes and tumor immunity. Carcinogenesis 2015, 36, 420-428. [CrossRef]

282. Gannon, P.O.; Poisson, A.O.; Delvoye, N.; Lapointe, R.; Mes-Masson, A.M.; Saad, F. Characterization of the intra-prostatic immune cell infiltration in androgen-deprived prostate cancer patients. J. Immunol. Methods 2009, 348, 9-17. [CrossRef]

283. Trigunaite, A.; Dimo, J.; Jørgensen, T.N. Suppressive effects of androgens on the immune system. Cell. Immunol. 2015, 294, 87-94. [CrossRef]

284. Malkin, C.J.; Pugh, P.J.; Jones, R.D.; Jones, T.H.; Channer, K.S. Testosterone as a protective factor against atherosclerosisImmunomodulation and influence upon plaque development and stability. J. Endocrinol. 2003, 178, 373-380. [CrossRef]

285. Yao, Q.M.; Wang, B.; An, X.F.; Zhang, J.A.; Ding, L. Testosterone level and risk of type 2 diabetes in men: A systematic review and meta-analysis. Endocr. Connect. 2018, 7, 220-231. [CrossRef] [PubMed]

286. Malkin, C.J.; Pugh, P.J.; Jones, R.D.; Kapoor, D.; Channer, K.S.; Jones, T.H. The Effect of Testosterone Replacement on Endogenous Inflammatory Cytokines and Lipid Profiles in Hypogonadal Men. J. Clin. Endocrinol. Metab. 2004, 89, 3313-3318. [CrossRef] [PubMed]

287. Agostino, P.; Milano, S.; Barbera, C.; Di Bella, G.; La Rosa, M.; Ferlazzo, V.; Farruggio, R.; Miceli, D.M.; Miele, M.; Castagnetta, L.; et al. Sex hormones modulate inflammatory mediators produced by macrophages a. Ann. N. Y. Acad. Sci. 1999, 876, 426-429. [CrossRef]

288. Corcoran, M.P.; Meydani, M.; Lichtenstein, A.H.; Schaefer, E.J.; Dillard, A.; Lamon-Fava, S. Sex hormone modulation of proinflammatory cytokine and C-reactive protein expression in macrophages from older men and postmenopausal women. $J$. Endocrinol. 2010, 206, 217-224. [CrossRef]

289. Fijak, M.; Schneider, E.; Klug, J.; Bhushan, S.; Hackstein, H.; Schuler, G.; Wygrecka, M.; Gromoll, J.; Meinhardt, A. Testosterone Replacement Effectively Inhibits the Development of Experimental Autoimmune Orchitis in Rats: Evidence for a Direct Role of Testosterone on Regulatory T Cell Expansion. J. Immunol. 2011, 186, 5162-5172. [CrossRef] [PubMed] 
290. Chao, T.-C.; Alten, P.J.V.; Walter, R.J. Steroid Sex Hormones and Macrophage Function: Modulation of Reactive Oxygen Intermediates and Nitrite Release. Am. J. Reprod. Immunol. 1994, 32, 43-52. [CrossRef]

291. Friedl, R.; Brunner, M.; Moeslinger, T.; Spieckermann, P.G. Testosterone inhibits expression of inducible nitric oxide synthase in murine macrophages. Life Sci. 2000, 68, 417-429. [CrossRef]

292. Rettew, J.A.; Huet-Hudson, Y.M.; Marriott, I. Testosterone Reduces Macrophage Expression in the Mouse of Toll-Like Receptor 4, a Trigger for Inflammation and Innate Immunity. Biol. Reprod. 2008, 78, 432-437. [CrossRef]

293. Quintar, A.A.; Roth, F.D.; De Paul, A.L.; Aoki, A.; Maldonado, C.A. Toll-like receptor 4 in rat prostate: Modulation by testosterone and acute bacterial infection in epithelial and stromal cells. Biol. Reprod. 2006, 75, 664-672. [CrossRef]

294. Akira, S.; Takeda, K. Toll-like receptor signalling. Nat. Rev. Immunol. 2004, 4, 499-511. [CrossRef] [PubMed]

295. Chen, C.C.C.W.; Jian, C.Y.; Lin, P.H.; Chen, C.C.C.W.; Lieu, F.K.; Soong, C.; Hsieh, C.C.; Wan, C.Y.; Idova, G.; Hu, S.; et al. Role of testosterone in regulating induction of TNF- $\alpha$ in rat spleen via ERK signaling pathway. Steroids 2016, 111, 148-154. [CrossRef] [PubMed]

296. Cutolo, M.; Accardo, S.; Villaggio, B.; Barone, A.; Sulli, A.; Coviello, D.A.; Carabbio, C.; Felli, L.; Miceli, D.; Farruggio, R.; et al. Androgen and estrogen receptors are present in primary cultures of human synovial macrophages. J. Clin. Endocrinol. Metab. 1996, 81, 820-827. [CrossRef] [PubMed]

297. McCrohon, J.A.; Death, A.K.; Nakhla, S.; Jessup, W.; Handelsman, D.J.; Stanley, K.K.; Celermajer, D.S. Androgen receptor expression is greater in macrophages from male than from female donors: A sex difference with implications for atherogenesis. Circulation 2000, 101, 224-226. [CrossRef]

298. Cioni, B.; Zaalberg, A.; van Beijnum, J.R.; Melis, M.H.M.; van Burgsteden, J.; Muraro, M.J.; Hooijberg, E.; Peters, D.; Hofland, I.; Lubeck, Y.; et al. Androgen receptor signalling in macrophages promotes TREM-1-mediated prostate cancer cell line migration and invasion. Nat. Commun. 2020, 11, 4498. [CrossRef] 